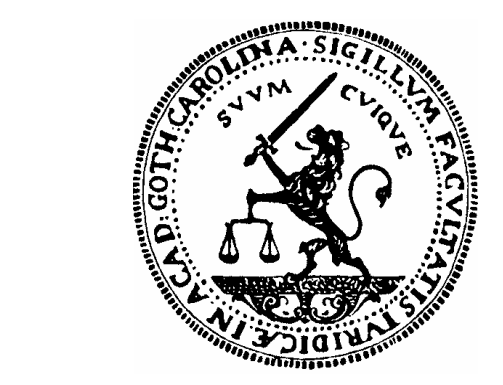

FACULTY OF LAW

University of Lund

Nina Larsaeus

\title{
THE RELATIONSHIP BETWEEN SAFEGUARDING INTERNAL SECURITY AND COMPLYING WITH INTERNATIONAL OBLIGATIONS OF PROTECTION.
}

The Unresolved Issue of Excluded Asylum Seekers

\author{
Master thesis \\ 20 points
}

\author{
Supervisors: \\ Gregor Noll \\ Peter Macalister-Smith \\ Public International Law
}

Spring 2003 


\section{Contents}

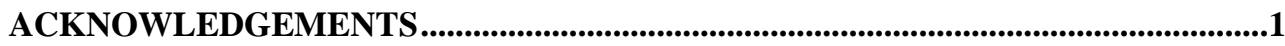

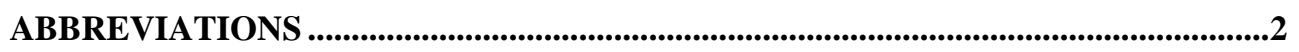

1 INTRODUCTION ..........................................................................................................

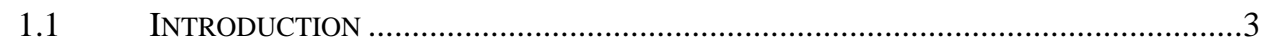

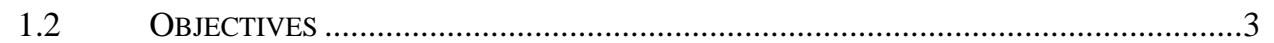

1.3 METHOD AND DELIMITATIONS ....................................................................4

2 THE INTERNATIONAL FRAMEWORK......................................................6

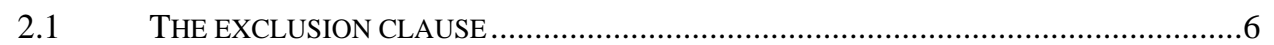

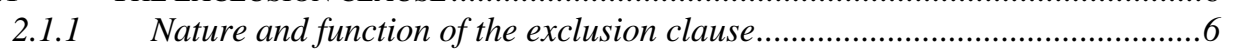

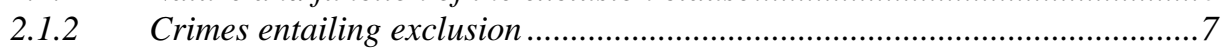

2.1.3 Human rights bar to removal .................................................................... 8

2.2 AUT DEDERE AUT JUDICARE - SOLVING THE ISSUE OF IMPUNITY? .........................

2.2.1 An obligation under the Refugee Convention?.............................................10

2.2.2 An obligation founded in international criminal law? ................................11

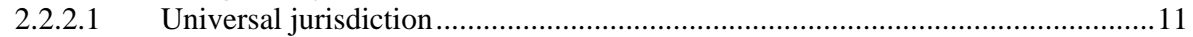

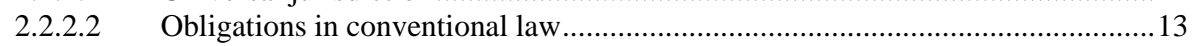

2.2.2.3 The case for an obligation under customary law ..................................................18

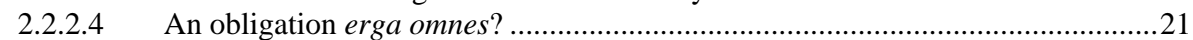

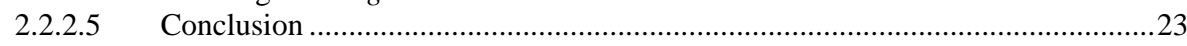

2.3 INTERNATIONAL OBLIGATIONS OF PROTECTION ..............................................25

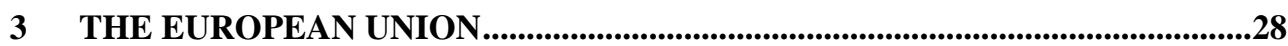

“AN AREA OF FREEDOM, SECURITY AND JUSTICE” .........................................28

3.2 THE EXCLUSION CLAUSE OF THE QUALIFICATION DIRECTIVE..........................28

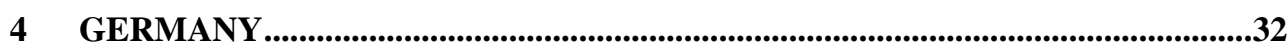

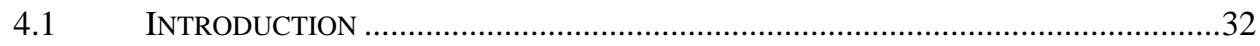

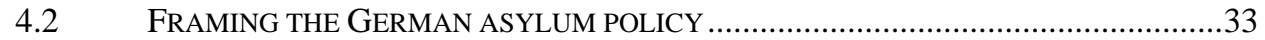

4.2.1 EU harmonisation and change of policies ...................................................34

4.2.2 The position of the Refugee Convention in German law ...............................35

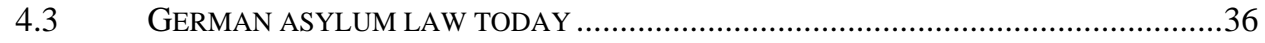

4.3.1 The German Aliens Act (AuslG) .............................................................36

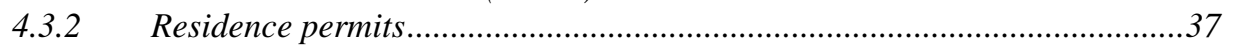

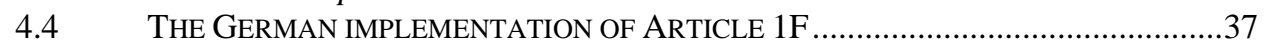

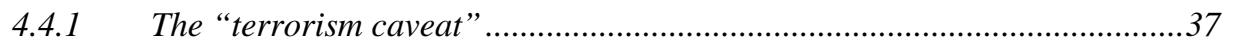

4.4.2 The introduction of the exclusion clause by the

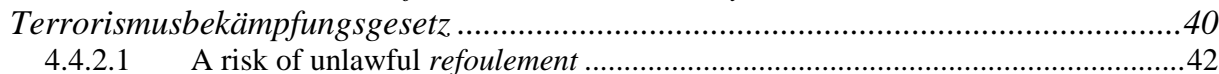

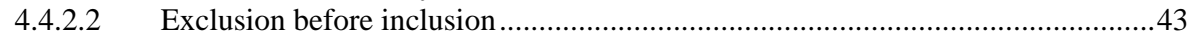

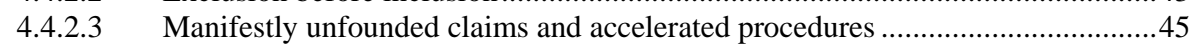

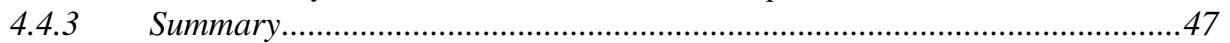

4.5 UNIVERSAL JURISDICTION IN GERMANY ....................................................49

4.5.1 The necessary legal framework to satisfy international obligations? ............50

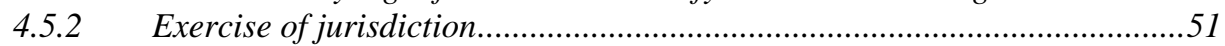

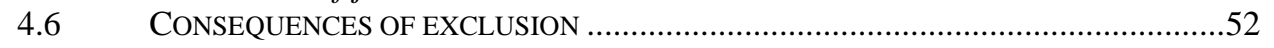

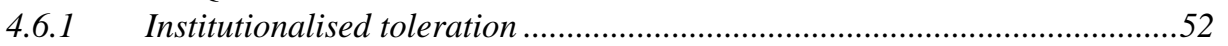

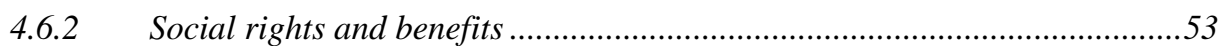

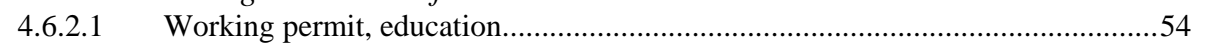

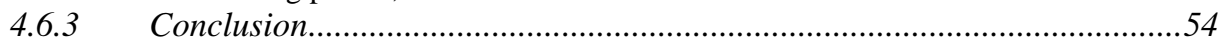

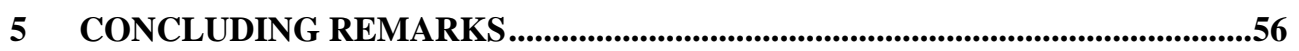

5.1 A PARTIAL LEGAL OBLIGATION TO PROSECUTE ................................................56 


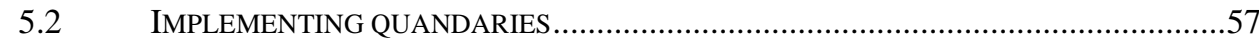

SUPPLEMENT A: EXCERPTS FROM INTERNATIONAL LAW.............................60

SUPPLEMENT B: EXCERPTS FROM EUROPEAN COMMUNITY LAW .............61

SUPPLEMENT C: EXCERPTS FROM GERMAN LAW .......................................62

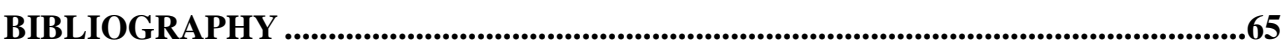

INTERNATIONAL INSTRUMENTS AND DOCUMENTS .....................................70

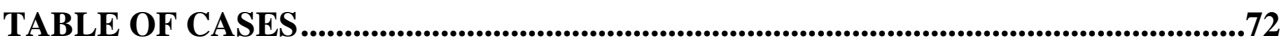




\section{Acknowledgements}

I owe a first word of appreciation to my main supervisor Gregor Noll. His continuous encouragement and insightful criticism has been and remains invaluable. I am especially grateful to Peter Macalister-Smith of the Max Planck Institute who kindly welcomed me to the Institute and supervised my research during two months in Heidelberg.

Furthermore, I would like to thank Vilhelm Persson for discussing some key ideas in the early phase of this study. Martin Ott, research assistant at the Lehrstuhl für Öffentliches Recht, Völker- und Europarecht, Humboldt Universität, greatly contributed by reading and commenting on a draft of the German section. Georg Classen of the Flüchtlingsrat Berlin shared his extensive experience of German asylum practices with me.

Finally, my warmest thanks and appreciation are extended to Thomas Weber for his insistence on analytical precision and his loving support. 


\section{Abbreviations}

\begin{tabular}{|c|c|}
\hline CAT84 & Convention Against Torture \\
\hline CSR51 & Convention Relating to the Status of Refugees \\
\hline AsylVfG & Asylum Procedure Act, Asylverfahrensgesetz \\
\hline AsylbLG & Asylbewerberleistungsgesetz \\
\hline AuslG & $\begin{array}{l}\text { Act Concerning Entry and Residence of Aliens in the } \\
\text { Territory of the Federal Republic of Germany, } \\
\text { Ausländergesetz }\end{array}$ \\
\hline BAFL & $\begin{array}{l}\text { Federal Office for Recognition of Foreign Refugees, } \\
\text { Bundesamt für die Anerkennung ausländischer Flüchtlinge }\end{array}$ \\
\hline BVerwG & $\begin{array}{l}\text { German federal administrative court, Bundesverwaltungs- } \\
\text { gericht }\end{array}$ \\
\hline BVerfG & German Constitutional Court, Bundesverfassungsgericht \\
\hline ECHR50 & European Convention of Human Rights \\
\hline ECtHR & European Court of Human Rights \\
\hline VStGB & $\begin{array}{l}\text { Code of Crimes against International Law, } \\
\text { Völkerstrafgesetzbuch }\end{array}$ \\
\hline ICCPR66 & International Covenant on Civil and Political Rights \\
\hline ICSECR66 & $\begin{array}{l}\text { International Covenant on Social Economic and Cultural } \\
\text { Rights }\end{array}$ \\
\hline TEC & Treaty establishing the European Community \\
\hline
\end{tabular}




\section{Introduction}

\subsection{Introduction}

In this time of 'war against terrorism' Article $1 \mathrm{~F}$ of the Refugee Convention (CSR51), the "exclusion clause" has attracted renewed attention. The Article enables, or indeed obliges, states to exclude from international protection anyone who, due to his or her serious crimes is deemed not to deserve the refugee status. The purpose of exclusion is twofold: to prevent impunity and to maintain the integrity of the institution of asylum. While, however, the latter has arguably been achieved, much remains to be done when it comes to the first objective. Correctly implemented, it is argued that the principle of aut dedere aut judicare may provide a solution to the moral dilemma of excluding individuals in need of international protection for the greater good of preserving the integrity of the Refugee Convention. It is my impression, though, that while extradition law has developed since 1951, the national implementation of international criminal law has been incomplete or inconsistent. Whereas the exclusionary part of the provision has been the object of considerable scholarly attention, the fate of the people excluded has been investigated to a lesser extent. This essay shall focus on a very particular segment of this group; individuals who, due to their alleged involvement in serious crimes have been excluded from refugee status but who for various reasons can neither be expelled or extradited nor be prosecuted by the host state. Excluded from the rights and privileges awarded to convention-refugees these persons are effectively left to the mercy of the state both in terms of legal status and social conditions. It should thus be of interest to investigate not only states' international obligations in respect to this group but also to examine actual state practice. What legal status do these aliens have, what social rights and benefits, and, to the extent that can be discerned, what is the political rationale behind states' strategies?

\subsection{Objectives}

In respect of the exclusion clause there are largely three issues requiring attention: who should be excluded; by what procedure should this be determined; and what shall happen with excluded individuals. Although all these questions are essentially interrelated, the focus of this study is not the full examination of all issues. Instead, my aim is to construct a clear and decisive account of the one part that has, so far, been only superficially 
investigated, namely state obligations to prosecute excluded individuals and the legal situation of those excluded.

This study shall take a three-level approach: In the first section I shall investigate the international legal framework to establish the requirements under international law. Once a state has excluded a person suspected of serious criminal acts, is it also its duty to punish those crimes? Or, if not, what legal status and economic- and social assistance is such an excluded person entitled to?

In a second section the emergence of a possible European solution to the problem of excluded, non-removable individuals will be discussed.

The third section looks at actual state practice, focusing on one country, Germany. Germany is interesting in as much as its implementation of Article $1 \mathrm{~F}$ was carried out in a clear post 11 September sentiment, giving reasons to believe that the issue of state security, contra refugee protection should have been particularly influential. Hence, the legal reasoning behind the legislation will presumably reflect the government opinion of the role of the exclusion clause in a post 11 September context. This section shall therefore examine the German implementation of the exclusion clause, both with regard to the actual regulation and its wider implications. How has it tackled the post exclusion phase, how does Germany regulate prosecution and how does it deal with excluded individuals' legal status and social rights?

While the first two sections are rather descriptive, the section on Germany will add a normative dimension. Hence it shall not only describe the legal implementation of the exclusion clause but also discuss the suitability of that approach. To what extent does it satisfy the intentions of the 1951 Refugee Convention and how well does it meet the goals of the German legislator?

\subsection{Method and delimitations}

As the scope of this thesis does not justify the independent examination of state practice and primary legal sources in all its sections, the primary means of this study will be the examination and qualified discussions of the legal doctrine. Throughout the study I have sought practical evidence of state practice as well as statistical evidence to test theories. Especially in the third part of this study, access to immigration board statistics and criminal records of excluded individuals would have been very useful. To date 
however, no official statistical data exist on the number of asylum seekers excluded on the basis of Article $1 \mathrm{~F}$ or of the number of prosecutions issued on the basis of information from asylum-determination processes. With regard to the part on Germany, I have sought to compensate the lack of practical evidence with formal and informal contacts and interviews with representatives both from the German government and German NGO:s. Nevertheless, this is primarily an analysis of the doctrinal writings, a full empirical investigation of the post-exclusion phase remains to be done. 


\section{The international framework}

\subsection{The exclusion clause}

\subsubsection{Nature and function of the exclusion clause}

When the exclusion clause was introduced by the 1951 Refugee Convention this was a new feature in the eligibility decision of refugee assistance. Previous refugee instruments had had no such clause, which proved to be a shortcoming in the chaotic aftermath of the German defeat. ${ }^{1}$ Formulating Article $1 \mathrm{~F}$ the drafters are reported to have been guided by a twofold objective; the wish to protect the refugee status from abuse while preventing impunity from justice. ${ }^{2}$ The notion of certain individuals being held "undeserving" of international protection seems to imply a moral and ethical stand beyond simply not meeting the criteria. In its "Note on the Exclusion Clauses" the UNHCR Executive Committee affirms this reading, declaring that "the protection as a refugee is related to the intrinsic links between ideas of humanity, equity, and the concept of refuge." ${ }^{3}$ It is believed that by excluding such "undeserving" individuals the integrity of the institution of asylum would be preserved and state support of the CSR51 strengthened. ${ }^{4}$

When the criteria of Article $1 \mathrm{~F}$ are met, the provisions of the convention "shall not apply" and the asylum seeker is at once shut out of the considerable protective framework otherwise offered to persons fulfilling the criteria in Article 1A. The phrasing seems categorical and was certainly intended to be so. An alternative, optional phrasing was turned down on a

\footnotetext{
${ }^{1}$ Grahl-Madsen, A., The Status of Refugees in International Law, I (Leyden: Sijthoff, 1966) p. 262.

${ }^{2}$ Gilbert, G., Current Issues in the Application of the Exclusion Clauses', in UNHCR, Global Consultations on International Protection in the context of the $50^{\text {th }}$ anniversary of the 1951 Convention relating to the Status of Refugees. Citing the travaux préparatoires; Conference of the Plenipotentiaries on the status of Refugees and Stateless Persons, Summary Record of the Twenty-fourth Meeting, A/CONF.2/SR.24, 27 November 1951, Statements of Herment, Belgium and Hoare, United Kingdom; and Weis, P., (ed.) The Refugee Convention, 1951: the Travaux Préparatoires Analysed with a Commentary, (Cambridge: Grotius Publications, 1995). Grahl-Madsen, emphasis the need to make sure that the Article did not impair the implementation of the evolving extradition law. GrahlMadsen, A. The Status of Refugees. See also Paragraph (d) of the GA Resolution on 12 February 1946 [UN Doc. A/45]. ("No action taken [...] shall be of such a character as to interfere in any way with the surrender and punishment of war criminals, quislings and traitors, in conformity with present or future international arrangements and agreements". As cited in Grahl-Madsen, A, The Status of Refugees, p. 271.

${ }^{3}$ Standing Committee: Note on the Exclusion Clauses (30 May 1997), [EC/47/SC/CRP.29].

${ }^{4}$ Ibid.
} 
French initiative favouring the present, mandatory, exclusion. ${ }^{5}$ Over the years, however, possibly as a result of what van Krieken calls the "blurred interpretations of good and evil" of the cold war, the original, uncompromising, implementation of the provision was diluted. ${ }^{6}$ Asylum was habitually granted to anyone alleging persecution by the enemy side and serious crimes were excused with an underlying reference to the good cause.

Only recently, inter alia as a result from the experiences from the Great Lakes and the Yugoslav wars, the background and past activities of asylum seekers have again come into focus. In the wake of 11 September 2001 the exclusion clause is commonly believed to experience a renaissance. From a human rights point of view this is a development worth watching closely. Mary Robinson and late Sergio Vieira de Mello both expressed serious concerns about the possible impact of Resolution 1373 on human rights worldwide. $^{7}$

Nevertheless, states have a legitimate interest in safeguarding their internal security just as the individual refugee is depending on the trust and cooperation of states. Under these circumstances, the exclusion clause must be regarded as the appropriate device for making the necessary distinction between persons themselves active in prosecution and those genuinely in need of international protection. Correctly applied and practised, Article $1 \mathrm{~F}$ presents a solution to the inevitable conflict of protecting refugees and safeguarding state interests of peace and stability which is in conformity with the Refugee Convention.

\subsubsection{Crimes entailing exclusion}

By consulting state practise and various international instruments in the related fields of international humanitarian law and international criminal law, it is possible to reach a fairly clear picture of the group concerned in relation to the exclusion clauses. Already the Charter of the International Military Tribunal (IMT Charter Art 6) gives a good description of what acts

\footnotetext{
${ }^{5}$ Grahl-Madsen, A., The Status of Refugees p. 263. See also Hathaway, J., \& Harvey, C., 'Framing refugee protection in the new world order', Cornell International Law Journal 34 (2001) 257-230.

${ }^{6}$ Van Krieken, P., 'Germany and Article 1F: "the Urgent Need to Implement a Basic Principle”, AWR-Bulletin: Vierteljahresschrift für Flüchtlingsfragen, 3-4 (2000) p. 189.

${ }^{7}$ U.N. Doc.S/RES/1373 (2001). ("The Security Council [...] calls upon all States to [...] take appropriate measures [...] before granting refugee status, for the purpose of ensuring that the asylum-seeker has not planned, facilitated or participated in the commission of terrorist acts”.) See reference to speeches by the UN High Commissioners in HRW, In the Name of Counter-Terrorism: Human Rights Abuses Worldwide A Human Rights Watch Briefing Paper for the 59th Session of the United Nations Commission on Human Rights March 25, 2003.
} 
constitute crimes against peace, war crimes, and crimes against humanity. ${ }^{8}$ It should be kept in mind however, that the CSR51 is thought to be a "living instrument" and any analysis will not be complete without considering the statutes of e.g. ICTY, ICTR and ICC. ${ }^{9}$ In respect to Article 1F (a) the reference to international instruments is explicit. It is argued in the doctrine, that the interpretation of "non-political crimes" as well as "acts contrary to the purposes and principles of the United Nations" should also be construed in that same context. ${ }^{10}$ UNHCR has suggested that, in the absence of any "political factors" a presumption of serious crime may be raised by evidence of homicide, rape, child molesting, wounding, arson, drugs trafficking, and armed robbery. ${ }^{11}$ A comparison with the exclusion provision of Article 14.2 of the 1948 Universal Declaration of Human Rights also shows that Article $1 \mathrm{~F}$ has a relatively wide group of addressees. It excludes not only those actually prosecuted for certain crimes and acts but anyone with respect to whom there are serious reasons for considering the same.

\subsubsection{Human rights bar to removal}

Usually the application of the exclusion from refugee status will lead to the expulsion or extradition of that person from the country. Both extradition and expulsion from the territory may however be impossible due to legal obstacles. A number of human rights instruments, such as the Convention Against Torture (CAT84), the International Covenant on Civil and Political Rights (ICCPR66) and the European Convention of Human Rights (ECHR50), provide alternate protection against refoulement as a consequence of certain treatments or punishments. The Convention Against Torture explicitly prohibits the return of any individual who would face torture. $^{12}$ Unlike the CSR51 the CAT84 makes no exceptions for "undeserving" persons and has no derogation provisions. In the European context the ECHR50 has long been interpreted to comprise a prohibition of

\footnotetext{
${ }^{8}$ Charter of the International Military Tribunal, 82 U.N.T.S. 280, Article 6 of the charter is available also as an annex (Annex V) to the UNCHR Handbook.

${ }^{9}$ The literature here is ample and makes a reiteration of the information superfluous, see e.g. van Krieken, P., (ed.), Refugee law in context. The exclusion clause, (The Hague: T.M.C. Asser Press, 1999); and International journal of refugee law, 12 (2000) Special Supplementary Issue, two volumes which, dealing exclusively with the exclusion clause, both focus on the interpretation and application.

${ }^{10}$ Van Krieken, P., 'Germany and Article 1F'.

${ }^{11}$ Goodwin-Gill, G., The Refugee in International law (Oxford: Claredon, 1996), p.107 referring to personal contacts with the UNHCR in 1980.

${ }^{12}$ CAT84 Article 3. For an examination on the potentials of CAT84 in the protection of refugees, and a discussion on case-law see Gorlick, B., 'The Convention against Torture: a complementary protection regime for refugees', International Journal of Refugee Law 11/3 (1999) 479-495.
} 
refoulement. ${ }^{13}$ The European Court of Human Rights (ECtHR) has repeatedly affirmed that the protection is absolute and should prevail even under difficult circumstances such as the fight against terrorism and organised crimes or even in times of public emergency. ${ }^{14}$

In recent years the "human rights bar to removal" has been increasingly utilised by individuals seeking state protection, possibly as a response to an ever-weakening system of refugee protection. ${ }^{15}$ It must be noted, however, that while the human rights prohibition of refoulement may provide the individual with a right to stay, it does not like the Refugee Convention, entail a regulated status. Neither does it provide any solution to the question of how to handle those individuals who are excluded from refugee status on the basis of a suspicion of serious crimes but who cannot be expelled or extradited.

\subsection{Aut dedere aut judicare - solving the issue of impunity?}

In discussions of the treatment of excludable persons who cannot be expelled or extradited due to a human rights bar to removal, general references are often made to the principle of aut dedere aut judicare. In December 2001, the European Commission issued a seminal working paper called "The relationship between safeguarding internal security and complying with international protection obligations and instruments”, in which it sets out the context within which the Commission will address issues of internal security and international obligations of protection. In the working document, the Commission confirmed the view that "the aut dedere aut judicare principle provides a solution of the inherent contradiction between the State's need, and indeed obligation, to combat acts such as terrorism, and the individual's entitlement to protection against refoulement." "Indeed, it seems easy to agree with the Commission in this respect. In view of the purpose of the exclusion clause; upholding the integrity of the institution of asylum and to prevent impunity from justice, it seems to make sense that a state that does not expel or extradite a suspected criminal should instead prosecute that person under its own jurisdiction. By

\footnotetext{
${ }^{13}$ See Soering v. the United Kingdom, European Court of Human Rights, 7 July 1989, Series A no. 161

${ }^{14}$ See e.g. Chahal v. the United Kingdom, European Court of Human Rights, 15 November 1996, Reports of Judgments and Decisions 1996-V.

${ }^{15}$ Gorlick, B., p. 495.

${ }^{16}$ Commission Working Document The relationship between safeguarding internal security and complying with international protection obligations and instruments COM(2001)743 final. At p. 13.
} 
disqualifying persons suspected of serious crimes from obtaining refugee status the first of the Convention objectives may have been satisfied. If states exclude persons in order to uphold the Convention objectives, they could therefore be expected to fulfil the second criterion by expelling the suspected criminal to a state where he or she can be prosecuted or alternatively, to prosecute the individual under its own jurisdiction. This seems to be both systematically correct and a moral obligation. The question however, is how well the principle of aut dedere aut judicare is applicable in this respect, and this is a question that the Commission does not answer. Is there in fact an international obligation to prosecute un-removable individuals, flowing from the very purpose of the Refugee Convention, from international criminal law or perhaps elsewhere?

\subsubsection{An obligation under the Refugee Convention?}

If central features of the CSR51objectives were to protect the integrity of the Convention and to prevent impunity, what significance shall the object and purpose of any convention have to its interpretation today? More specifically, is it possible to base any legal obligation on the intentions behind a convention? The answer to this question, can be either yes or no, depending on the circumstances. The Vienna Convention on the law of the treaties state that "[a] treaty shall be interpreted in good faith in accordance with the ordinary meaning to be given to the terms of the treaty in their context and in the light of its object and purpose."17 Obviously the object and purpose of the convention does play a role in the interpretation. The question however is at what stage of the interpretation procedure that the object and purpose become relevant. Linderfalk has established a hierarchical methodology answering this question; only if the ordinary meaning of the treaty does not provide a clear result should recourse be taken to the "object and purpose". ${ }^{18}$ With this strategy we can draw a speedy conclusion. Turning to the ordinary meaning of the Refugee Convention, neither in Article $1 \mathrm{~F}$ nor elsewhere in the Convention is there a reference to an obligation of prosecuting those suspected of crimes leading to exclusion.

Under such circumstances the operation has come to an end and it is not justifiable to proceed to the level of object and purpose for further information. Indeed, if parties intended the prevention of impunity to be the main objective of the convention, why did they not choose to include a provision with that meaning? It seems that the only viable conclusion must be

\footnotetext{
${ }^{17}$ VCLT Art 31, UN Doc A/Conf 39/28, UKTS 58 (1980), 8 ILM 679.

${ }^{18}$ Linderfalk, U., Om tolkning av traktater (Studentlitteratur: Lund, 2001). See particularly chapter 10 .
} 
that the CSR51 does not regulate the treatment of excluded persons in any way. It may be in line with the spirit of the convention but the Refugee Convention, as such, does not demand that states prosecute those excluded.

\subsubsection{An obligation founded in international criminal law?}

If refugee law does not oblige states to prosecute excluded individuals what about international criminal law? We know that some of the crimes mentioned in Article 1F have attracted much attention by the international community and, indeed, have been subject to international legal sanctions ever since the Nuremberg tribunals. It may seem surprising therefore to note how reluctant refugee scholars have been to draw on the results from international criminal law. The truth is, however, that although a substantial deal of research has been made exactly on the issue of a suggested obligation to prosecute certain crimes, opinions still vary considerably. While refugee law and practice has evolved from the rather solid foundation of the 1951 Convention, the same cannot be said for international criminal law. That process rather appears to have taken place episodically, sprung from specific circumstance such as the Nuremberg tribunals, the terrorism wave in the 70s, and the establishment of the international ad hoc criminal tribunals. This has probably contributed to the complex character of international criminal law and as Joseph Rikhof points out, the far from consistent development has led to considerable overlaps between a number of international crimes. ${ }^{19}$ Under these circumstances it has been hard to establish any general principle on mandatory universal jurisdiction and even harder to apply it to the set of acts and crimes enlisted in Article $1 \mathrm{~F}$ of the CSR51 that only in part corresponds with the acts traditionally addressed by international criminal law. Nonetheless, in view of the underdeveloped legal doctrine in this particular area of refugee law, it seems that the answer to our question will have to be sought precisely within this complex field of international criminal law. In the following I shall therefore attempt to bring the two areas together and answer the question whether there is in fact an international legal obligation to prosecute excluded persons.

\subsubsection{Universal jurisdiction}

Universal jurisdiction is normally not accepted under international law, which usually requires a link of territory or nationality as the basis for a state's exercise of criminal jurisdiction. The reason of course, is that a person should not be punished elsewhere for an act that may have been lawful in the state where it was committed. ${ }^{20}$ This objection however, has

\footnotetext{
${ }^{19}$ Rikhof, J., ‘Access, Asylum and Atrocities: An Unholy Alliance?’, Refuge, Vol. 19 Number 4, p.100-115. At p. 105.

20 See Malanczuk, P,. Akehurst's Modern Introduction to International Law. 7th ed. (London/ New York: Routlegde, 1997), p.112.
} 
seemed inadequate for those acts that are regarded as crimes in all countries, by international treaties or international customary law, and consequently a practice has come to evolve where universal jurisdiction is nonetheless accepted for a limited number of crimes. Such crimes have been regarded "crimes of international concern" and the perpetrators hostis humani generis, or enemies of mankind. Although there is an agreement that the principle of universal jurisdiction should only apply to the most serious of crimes it is still disputed which crimes meet this description. The exact list varies both among scholars and states and ranges from a small number of "core crimes" to a rather extensive list. ${ }^{21}$ With regard to piracy and slave trade there is a long tradition in international law accepting universal jurisdiction. Today however, focus is rather placed on crimes against humanity, genocide and grave beaches of and serious crimes against international humanitarian law, where the right to prosecute has evolved as a matter of customary international law. ${ }^{22}$ In yet a number of cases, jurisdiction is explicitly established in international treaties, ${ }^{23}$ which has led some authors to conclude that these crimes may also be subject to universal jurisdiction. ${ }^{24}$ This assumption, however, seems to be the result of a widespread confusion of definitions. Since conventions as such are effective only between the parties to the conventions they can never apply to the whole community of states (lest of course, there be a parallel principle of international customary law to the same meaning, which again is a separate issue). It is difficult to see how the term universal jurisdiction, in its strict sense, could at all be applicable where a number of states have agreed to share their right to adjudicate. Certainly, these treaties provide for the exercise of (multiple) state jurisdiction, but this is not the same as to say that they also invoke the principle of universal jurisdiction. ${ }^{25}$ Although probably sufficiently accurate for most purposes, such a terminology does not accommodate the distinctions necessary for the analysis in this chapter and

\footnotetext{
${ }^{21}$ The Restatement provides a rather long list of crimes subject to universal jurisdiction, including "piracy, slave trade, attacks on or hijacking of aircraft, genocide, war crimes, and perhaps certain acts of terrorism". Restatement (Third) of the Foreign Relations Law of the United States, para. 404,. Shaw, on the other hand mentions only piracy and war crimes as subjects of universal jurisdiction. Shaw p. 414

22 Sadat, L. N., 'Redefining Universal Jurisdiction', New England Law Review, 2001 Vol. 35 p 241-263 at p. 244.

${ }^{23}$ See the 1949 Geneva Conventions, the 1973 international convention on the suppression and Punishment of the Crime of Apartheid and the 1984 Convention against Torture and other Cruel, Inhuman and Degrading Treatment or Punishment. More recent examples of international conventions arguably raising the principle of universal jurisdiction are found in relation to the hijacking of aircraft, terrorism, hostage-taking, drug-trafficking and counterfeiting of currency.

${ }^{24}$ See e.g. Malanczuk, P., at 112-113, who, although noticing the ambiguity of the definition, does not himself strictly uphold the distinction between universal jurisdiction on the one hand and treaty based jurisdiction on the other.

${ }^{25}$ This objection seems to be shared with Shaw, who suggests instead the term "quasiuniversal jurisdiction or multiple exercise of jurisdiction”.
} 
will therefore be avoided. It is true, though, that universal jurisdiction, traditionally considered a permissive basis for the exercise of jurisdiction by states "has become increasingly mandated by international treaties, to such a degree that some argue that the aut dedere aut judicare principle is now found in customary international law." ${ }^{26}$ From now on it shall therefore also be necessary to distinguish between the principle of universal jurisdiction and the principle of aut dedere aut judicare. The latter expression is essentially a modern adaptation of the phrase aut dedere aut punire used by Grotius in De Jure Belli ac Pacis to describe a natural right of an injured state to exact punishment, either itself or by the state hosting the suspect. ${ }^{27}$ The modern expression however, seems to suit the contemporary meaning better, as it does not, strictly speaking, imply an obligation to "punish" but rather to adjudicate or prosecute, or even just to "take steps towards prosecution”, ${ }^{28}$

\subsubsection{Obligations in conventional law}

While international law can be based either in custom or in black-letter law, the most straightforward way of locating international legal obligations is usually to examine the existence of international conventions carrying such provisions. Since the end of World War II a significant number of conventions have come to regulate the legal prosecution of individuals suspected of serious crimes. In 1949 the four Geneva Conventions were adopted, introducing a duty on all contracting parties both "to enact any legislation necessary to provide effective penal sanctions" for grave breaches and "to search for" and bring such persons before their own courts, regardless of their nationality or, alternatively, to hand them over to another state for prosecution. ${ }^{29}$ The First Additional Protocol extends the concept of grave breaches to a further set of acts that violate rules on the actual conduct of warfare. ${ }^{30}$ While the four Geneva Conventions have attained almost universal applicability ${ }^{31}$ and it is generally held that the provisions of the Conventions have since crystallised as customary law, the same cannot be said for the Additional Protocol I, which remains binding only to the contracting states. $^{32}$ The Geneva Conventions and the First Additional Protocol, however only apply to acts committed during international armed conflicts. As there are no similar references to grave breaches in the Second

\footnotetext{
${ }^{26}$ Sadat, L. N., p. 244

${ }^{27}$ Bassiouni, C. \& Wise, E., Aut Dedere Aut Judicare: The Duty to Extradite or Prosecute in International Law (Dordrecht: Nijhoff, 1995). At p. 4-5.

${ }^{28}$ Ibid.

291949 Geneva Conventions. See Articles 49, Art. 50, Art. 129 and Art 146 respectively.

${ }^{30}$ First Additional Protocol Arts. 11, 85, 88.

${ }^{31}$ In January 2003, 190 countries were parties to the four Geneva Conventions.

32 Tomuschat, C., 'The Duty to Prosecute Crimes Committed by Individuals', in H.-J. Cremer et al (eds.), Tradition und Weltoffenheit des Rechts. Festschrift für Helmut Stenberger (Berlin: Springer, 2002). P. 334.
} 
Additional Protocol, and no obvious state practice suggesting otherwise, it is hard to find support of a state obligation to prosecute war crimes in internal conflicts. ${ }^{33}$ As far as the permissive principle of universal jurisdiction is concerned, most authors seem to take the view that "not only grave breaches of the Geneva Conventions but also the 'Hague law' applicable in international armed conflict, as well as crimes arising in non-international armed conflicts" will give rise to such a right. ${ }^{34}$

An obligation similar to the aut dedere aut judicare formula of the Geneva Conventions was suggested by the International Law Commission also in regard of crimes against humanity. The ILC Draft Code of Crimes against the Peace and Security of Mankind ${ }^{35}$ was however never acted upon by the UN General Assembly and with the establishment of the International Criminal Court (ICC) in 1998 it has lost its practical importance. ${ }^{36}$ Before the adoption of the Rome Statute in 1998 there appears to have been some speculation as to whether the evolving notion of universal jurisdiction would find support in the Statute. ${ }^{37}$ Except from the preamble, "[r]ecalling that it is the duty of every state to exercise its criminal jurisdiction over those responsible for international crimes" the Statute says nothing on the issue of universal jurisdiction. Concurring with Tomuschat, I find it hard to derive from this sentence an implicit duty to prosecute. This is especially so in the light of the fact that the ICC cannot itself exercise universal jurisdiction but, short of a Security Council decision, is dependent on the consent either of the state of nationality or of the territorial state ${ }^{38}$ The question whether the statute supports the permissive principle of universal jurisdiction is still under debate. ${ }^{39}$ Either way, the legal literature, appears to be almost unanimous in the view that a universal jurisdiction exists in relation to crimes against humanity, as a matter of customary international

\footnotetext{
${ }^{33}$ Tomuschat is clearly against such a reading, see Tomuschat, C., 334.

${ }^{34}$ Broomhall, B., 'Towards the Development of an Effective System of Universal Jurisdiction for Crimes under International Law’, New England Law Review, 35/2 (2001) 404. See also Amnesty international concluding that "war crimes are now considered to include serious violations of international humanitarian law committed during noninternational armed conflict, including serious violations of common Article 3 of the Geneva Conventions, certain violations of Protocol II and some other conduct which, if it had been committed during an international armed conflict, would constitute war crimes". Amnesty international, Universal Jurisdiction. The Duty of States to Enact and Enforce Legislation. (AI index: IOR 53/005/2001), 2001 chapter 3 p.1.

358 ILC, $48^{\text {th }}$ Session, 6 May -26 July 1996, UN-Doc. A/CN.4/L.532.

36 Tomuschat, C., p. 338.

37 Tomuschat, C., pp. 348-349; Sadat, L. N., p. 243.

38 Tomuschat, C., "There can logically be no obligation upon an individual State to carry out what the international community itself is not willing to do.” p. 349.

${ }^{39}$ See e.g. Tomuschat $339-340$.
} 
law. ${ }^{40}$ With regard to three of the elements of the crime against humanity, namely the crime of apartheid, genocide and torture, there are explicit convention requirements to either 'prosecute or extradite' suspects. In 1984 the General Assembly adopted the Torture Convention with this stipulation (Arts 6, 7,12). ${ }^{41}$ Likewise the Apartheid Convention establishes a duty on states parties to suppress, prevent as well as to bring to trial and to punish, "in accordance with their jurisdiction persons responsible, or accused of" acts as defined in the Convention. ${ }^{42}$ Article 5 states that "persons charged [...] may be tried by a competent tribunal of any State Party to the convention which may acquire jurisdiction”. Read together with Article 6, the Convention is held to entail a principle of universal jurisdiction for the crime of apartheid, at least among states parties. ${ }^{43}$

With regard to the first of the crimes leading to exclusion in Article 1F, the crime against peace, there are no international conventions entailing a duty to prosecute. While a 'crime against peace' is essentially a 'crime of aggression', ${ }^{44}$ the concept of "aggression” is so immensely politicised that no international convention today entails an individual criminal responsibility for the crime. ${ }^{45}$ While the ICC Statute of Rome retains the option, subject to state party agreement on a definition, to add jurisdiction over the crime of aggression, this does not appear likely in the near future.

Summing up the findings with regard to crimes leading to exclusion under $1 \mathrm{~F}(\mathrm{a})$, we can conclude that all of these crimes are "crimes under international law". War crimes constituting grave breaches, torture, genocide and apartheid entail an obligation of aut dedere aut judicare as a matter of conventional law. Customary international law provides each state with a (permissive) universal jurisdiction also with regard to crimes against humanity. As for crimes against peace there is to date no permissive rule of universal jurisdiction nor an obligation to prosecute or extradite, in fact, pending a revision of the Rome Statute there does not appear to be any international forum entitled to try such crimes.

\footnotetext{
${ }^{40}$ See e.g. Tomuschat 340; Joyner, C. C., p. 159 (basing his argument it seems on a duty of erga omnes.) Amnesty international, Universal Jurisdiction. Chapter Five pp.1, 5-6; Restatement (Third), at § 404; Malanczuk, P., 113.

${ }^{41}$ Convention Against Torture and Other Cruel, Inhuman and Degrading Treatment or Punishment, Feb 4, 1985, 23 I.L.M. 1027, U.N. Doc. A/39/51 (1984).

${ }^{42}$ Apartheid Convention, Art. 6 (b).

${ }^{43}$ See Amnesty International, Universal jurisdiction chapter 5, pp. 3-4, referring in a note also to the preparatory work of the Convention.

${ }^{44}$ On this basis the UNHCR has taken the view that "“crime of aggression' should be included within the jurisdiction of the [ICC] Court”. UNHCR, UNHCR and the

Establishment of an International Criminal Court: Some Comments on the Draft Statute, available at <http://www.un.org/icc/unhcr.htm>.

${ }^{45}$ Tomuschat, C., p. 341.
} 
In the 1970s a new generation of conventions incorporating the aut dedere aut judicare principle took form. These conventions cover a broad range of crimes thought to be of international concern, but usually follow the structures of the first of these conventions, the 1970 Hague Convention for the Suppression of Unlawful Seizure of Aircraft. Here, "[t]he Contracting State in the territory of which the alleged offender is found shall, if it does not extradite him, be obliged, to submit the case to its competent authorities for the purpose of prosecution". ${ }^{46}$ Today there are a large number of such treaties; Bassiouni has found over 20 conventions establishing a duty to extradite or prosecute. ${ }^{47}$ Many of these, regulating for example hijacking, terrorism, hostage-taking and drug-trafficking may be directly relevant in regard of crimes leading to exclusion under Article 1F CSR51. The apparent political quality of some of these crimes should not be an obstacle. Although the wording of $1 \mathrm{~F}$ (b) seems to exempt all persons whose crimes are politically motivated, the general opinion is that there needs to be a form of "balancing act" ${ }^{48}$ When acts committed with a supposed political pretext are unproportionally brutal in relation to its alleged objective, causing serious bodily injury or taking civilian lives, this exception is held not to apply. Consequently, when a person is excluded from refugee status on the basis of a crime regulated in one of the conventions referred to above, state obligation to 'extradite or prosecute' that person usually follows, even if the motive for the act was political. This is not to say that the decision is always easy, especially the balancing act raises a number of intricate questions. Most of these issues however are generously discussed in the literature; further guidance can be sought in the doctrine on the 'political offence exception' in extradition law. ${ }^{49}$

\footnotetext{
${ }^{46}$ Hague Convention, Art 7.

${ }^{47}$ Bassiouni, C. \& Wise, E., Aut Dedere Aut Judicare.

${ }^{48}$ See Kälin, W. \& Künzli, J., 'Article 1.F(b): Freedom Fighters, Terrorists and the Notion of Serious Non-Political Crimes', International Journal of Refugee Law, Vol. 12, Special Supplementary Issue (2000), at 71-78; UNHCR Handbook. ("In determining whether an offence is "non-political" or is, on the contrary, a "political" crime, regard should be given in the first place to its nature and purpose i.e. whether it has been committed out of genuine political motives and not merely for personal reasons or gain. There should also be a close and direct causal link between the crime committed and its alleged political purpose and object. The political element of the offence should also outweigh its common-law character. This would not be the case if the acts committed are grossly out of proportion to the alleged objective. The political nature of the offence is also more difficult to accept if it involves acts of an atrocious nature.”) UNHCR Handbook at §152.

${ }^{49}$ See e.g. Storey, H., More Questions than Answers: The exclusion Clauses in the Light of September 11, Paper for joint IARLJ/ILPA Seminar 4 March 2002; Dugard, J., \& Van den Wyngaert, C., 'Reconciling Extradition with Human Rights', American Journal of International Law 92/1 (1998) 187-212. At 209-212; Kälin, W., \& Künzli, J., Article 1F(b), pp. 71-78.
} 
In Europe a somewhat different approach has been chosen with respect to the political offence exception. The 1977 European Terrorism Convention states explicitly that, among State Parties, there can be no such exceptions to the unlawful acts covered by the convention..$^{50}$

\section{A special note on terrorism}

In recent years, Article $1 \mathrm{~F}$ of the exclusion clause has been increasingly invoked in debates concerning terrorism. And, while it is true that there exist no internationally binding (or even generally accepted) definition of 'terrorism' there is a consensus on a number of crimes identified as terrorist in nature which could serve as a list, or enumerative definition, of the crime much like the list of conventions mentioned in the preceding section. ${ }^{51}$ Since however, the focus of Article $1 \mathrm{~F}(\mathrm{~b})$ and $1 \mathrm{~F}$ (c) is not like Article $1 \mathrm{~F}(\mathrm{a})$, set on specific crimes but rather on the underlying criminal act, ("serious nonpolitical crime" and "acts contrary to the purposes and principles of the United Nations"), the issue of definition, may not have any separate importance. As noted by the House of Lords in $T v$ Secretary of State, it is not whether a persons acts meet any definition of terrorism that needs to be established in an exclusion proceeding, but whether these acts meet the criteria of Article $1 \mathrm{~F}^{52}$ Yet, we cannot ignore the various statements recently delivered by the UN General Assembly and Security Council identifying "terrorism" as a violation of the purposes and principles of the United Nations and calling upon states to take measures to exclude individuals suspected of such crimes from refugee status. ${ }^{53}$ When construing

\footnotetext{
${ }^{50}$ Acts covered by the convention are: offences within the scope of the Convention for the Suppression of Unlawful Seizure of Aircraft; Suppression of Unlawful Acts against the Safety of Civil Aviation (Montreal Convention); any serious offence involving an attack against the life, physical integrity or liberty of internationally protected persons, including diplomatic agents; an offence involving kidnapping, the taking of a hostage or serious unlawful detention; use of a bomb, grenade, rocket, automatic firearm or letter or parcel bomb if this use endangers persons; or an attempt to commit any of the foregoing offences or participation as an accomplice of a person who commits or attempts to commit such an offence. European Convention on the Suppression of Terrorism, E.T.S. No.90, 27 January 1977, Art 1.

${ }^{51}$ Storey, H., p. 3.

${ }^{52} \mathrm{~T}$ v Secretary of State for the Home Department HOUSE OF LORDS [1996] 2 All ER 865, [1996] 2 WLR 766. As cited by Storey, H., p. 3. The full text can be found at $<$ http://www.refugeecaselaw.org/_RefugeeCases/22may1996algeriat.pdf > .

53 See UN G.A. Resolution on Measures to Eliminate International Terrorism (A/RES/49/60), and UN Security Council Resolution 1269 (1999), and 1373(2001) calling upon states to "take appropriate measures in conformity with the relevant provisions of national and international law, including international standards of human rights, before granting refugee status, for the purpose of ensuring that the asylum-seeker has not participated in terrorist acts”, (Operative clause 3 (f)). In the European context, the EU Council has pronounced that "[a]ppropriate measures shall be taken in accordance with the relevant provisions of national and international law, including international standards of human rights, before granting refugee status, for the purpose of ensuring that the asylumseeker has not planned, facilitated or participated in the commission of terrorist acts.”
} 
the meaning of terrorism in relation to Article $1 \mathrm{~F}(\mathrm{c})$ it seems therefore that the existing set of anti-terrorism conventions mentioned above will remain important in interpreting the scope of the $1 \mathrm{~F}$ (c). In as much as any of the anti-terrorism conventions are found to be directly applicable, state parties will also be bound by the rule of aut dedere aut judicare.

The set of anti-terrorism conventions can, however, also be used as Walter Kälin and Jörg Künzli suggest, to establish a list of elements "constituting the commonality of terrorist acts". ${ }^{54}$ Such a list could function as a guide of which acts may constitute "terrorism" under $1 \mathrm{~F} \mathrm{(c)} \mathrm{and} \mathrm{thus} \mathrm{be} \mathrm{"contrary} \mathrm{to}$ the purposes and principles of the United Nations.” As a referential guide, such a commonality list could probably be accepted even by non-state parties. It seems clear, however, that such a definition or a "commonality list" could never bind states to a duty of aut dedere aut judicare included in one of the conventions or, even less so, in the totality, or "commonality" of a number of conventions which they have not signed.

Nevertheless, with a slightly different starting point, this is exactly what would be the effect of the recent theories, claiming that the aut dedere aut judicare inherent to all of these conventions has developed a status of customary international law. The proposition of course is consequential, considering what it would mean to the fight against impunity. In the subsequent chapter this theory shall therefore be explored in closer detail.

\subsubsection{The case for an obligation under customary law}

While the scope of customary international law is not as clear-cut, it has the advantage of binding the whole collective of states irrespective of what treaties they have signed. As recognised by the ICJ Statute, international law consists of conventional law as well as "international custom as evidence of a general practice accepted as law." ${ }^{55}$ It is a well-established principle that this 'general practice' must be a reflection of a state's belief that this is the required course of action (opinio juris). ${ }^{56}$ It is however, not only state actions that matter but also what states do not do as well as what they say should be done as a matter of international law. In contemporary time this second part, the "speech act", is said to have gained importance in determining the existence of customary law. ${ }^{57}$

COUNCIL COMMON POSITION of 27 December 2001 on combating terrorism (2001/930/CFSP). Article 16.

${ }^{54}$ Kälin, W. \& Künzli, J., p. 75.

${ }^{55}$ ICJ statute of the international Court of Justice, 59 Stat. 1055. Article 38 (1) (b).

${ }^{56}$ See ICJ in Nicaragua Case on the issue of opinio juris.

${ }^{57}$ Bassiouni, C. \& Wise, E., Aut Dedere Aut Judicare, p. 46. 
Discussing a duty to prosecute, international criminal lawyers often make general referrals to such an obligation, or evolving obligation, of customary international law. Thorough justifications and legal support for this claim however, are rare. ${ }^{58}$ Consequently it is sometimes even hard to determine the actual scope of such an obligation. Is it a matter of particular offences in particular treaties (e.g. torture), a whole class of treaties (e.g. terrorist offences), or does the duty of aut dedere aut judicare perhaps apply to all international offences? The existence of a general duty to prosecute or extradite all international offences would have far-reaching consequences in exclusion cases.

Among those suggesting such an application in its broadest sense, are Enache-Brown and Fried. ${ }^{59}$ Discussing state practice and the large number of treaties incorporating the aut dedere aut judicare formula, Enache-Brown and Fried conclude that "if a state has signed and ratified a significant number of treaties containing the aut dedere aut judicare formula, then that state has demonstrated through this practice that aut dedere aut judicare is a customary norm." ${ }^{\prime 0}$ While I agree that the large number of such conventions may point at an acceptance of the principle, I do not think that this has necessarily given rise to an obligation over and above that set of conventions. For this I see two primary reasons. First, states no doubt adhere to all of these conventions with a belief that each and every one of them is advantageous to themselves or to the world community (or both). Possibly the wide adherence to the aut dedere aut judicare formula even "articulates the belief that aut dedere aut judicare is an accepted norm and that it is the most effective way of preventing certain forms of conduct" ${ }^{11}$ While it shows that states evidently wish to bind themselves to a principle of aut dedere aut judicare in a number of international offences, that does not automatically lend support to the second requirement of state practice; that they do so out of a conviction that this is the course of action required by law (opinio juris). In contrary, judging from the relatively small number of cases where states have actually initiated prosecutions in regard of war crimes or widespread human rights violations there is insufficient evidence that states genuinely consider themselves having an obligation to do so by international law. In fact, in as far as state practice go, even in regard of the most well-established of the international crimes, namely war crimes, "the obligation to prosecute or extradite imposed by the Geneva Conventions is

\footnotetext{
${ }^{58}$ Exceptions perhaps are Enache-Brown and Fried (note 59) and of course Bassiouni, whose argument is slightly different but just as far-reaching.

${ }^{59}$ Enache-Brown, C. \& Fried, A., 'The Obligation of Aut Dedere Aut Judicare in International Law’, McGill Law Journal, 42 (1998), 613-633.

${ }^{60}$ Enache-Brown, C. \& Fried, A., p. 629.

${ }^{61}$ Enache-Brown, C. \& Fried, A., p. 627.
} 
widely acknowledged to be a 'dead letter'”. ${ }^{62}$ When it comes to terrorism or less well-established conventional obligations, this ought to be even more so. Furthermore, although many state have ratified various conventions with the aut dedere aut judicare formula, it is far from all of these conventions that have gained the same wide application as the four Geneva Conventions or the Hague Convention. It is not inconceivable to think that the almost universal ratification of, for example, the Convention Against Torture may have crystallised into a duty to prosecute in relation to the crimes of torture as matter of customary international law. What Enache-Brown and Fried suggest, though, is not the establishment of an obligation with regard to a specific principle in some conventions but the universal obligation to prosecute or extradite suspects of all international crimes, not only of conventions entailing such a principle but all conventions, and in addition to international crimes defined in customary international law. The basis for their argument is founded not in a single convention but in the totality of conventions incorporating one or the other version of the aut dedere principle. I do not find it evident, however, that it is always possible to construe a general norm on the basis of various individual treaty provisions, or, put differently, that every treaty provision is intrinsically "generalisable". ${ }^{63}$ For identical treaty provisions to be supporting of a corresponding norm of customary international law Malanczuk requires as a minimum that the relevant provision be "widespread". ${ }^{64}$ This, however does not seem to account for the whole picture. There are many cases of bilateral treaty provisions, which are repeatedly included in a large number of treaties without reaching the level of customary international law. For example, despite the vast amount of extradition treaties signed among almost every state, there is no claim that extradition would therefore be an obligation binding by customary international law. On the contrary, states continue to exercise their sovereign rights for instance by granting asylum instead of extraditing a person. Apparently, it is not enough for a treaty provision to be widespread in order to generalise into a norm of customary international law. The impact of such a multiplied treaty provision seems to be determined rather by its legal setting and the weight of the norms otherwise regulating the area than the pure number of duplications. ${ }^{65}$ But if the "threshold [for a generalised treaty provision to be evidence of a general norm of international law] may vary depending on the perceived importance

\footnotetext{
${ }^{62}$ Bassiouni, C. \& Wise, E., Aut Dedere Aut Judicare, p. 45.

${ }^{63}$ See Malanczuk, P., p. 40.

${ }^{64}$ Ibid.

${ }^{65}$ Bassiouni, C., "[w] $[\mathrm{w}$ hether a treaty provision is capable of being treated as a general norm is therefore a matter of how well it fits in with other rules of international law". Aut Dedere aut Judicare, p. 48
} 
of the norm in question" 66 what are the standards that this should be measured against? The argument seems to demand a whole different approach to legal norms, weighting and examining their importance against some societal norm of desirable ends, and cherished values. In international and human rights law, not to mention refugee law, there are a number of such 'desirable ends', principles and ideas making up the moral substructure of international conventions.

I agree that the universal adoption of a convention with a specific provision may be evidence of a concurring norm of customary international law in relation to that particular area regulated by that convention, It is however, one thing to claim e.g., that because of the wide ratification of the Torture Convention with its provision of aut dedere aut judicare, states are under an obligation, as a matter of customary international law, to extradite or prosecute suspected torturers. It is a very different argument to claim that because of the large total number of treaties incorporating a provision of aut dedere aut judicare, states are bound to extradite or prosecute any suspect of any international crime. To establish such a far-reaching obligation would need arguments of a whole different magnitude than those so far presented by Enache-Brown/Fried and others.

\subsubsection{An obligation erga omnes?}

In the preceding section I advanced the theory that the generalisability of a treaty provision may be depending on its legal setting. If a common treaty provision does not conflict with existing norms of customary law such a provision was said to be "generalisable". ${ }^{67}$ If it does conflict with an existing norm, I suggest, that this norm will usually prevail before a provision, which is, strictly speaking not more than a treaty provision and not a customary norm. Some attention, however, should also be given to the hierarchy of the conflicting norms. Some norms are generally considered to be of such a magnitude that they cannot be over-ruled or out-trumped by any other norm that is not of the same rank. Such 'peremptory norms of general international law', or jus cogens, are said to compose the outer limit of states liberty to create local custom or make treaties. The principle of jus cogens is widely accepted and as of 1969 defined in the Convention on the Law of the Treaties as "a norm accepted and recognized by the international community of States as a whole as a norm from which no derogation is permitted and which can be modified only by a subsequent norm of general international law having the same character." ${ }^{68}$ While the VCLT provides a

\footnotetext{
${ }^{66}$ Bassiouni, C. \& Wise, E., Aut Dedere Aut Judicare p. 47

${ }^{67}$ Bassiouni, C. \& Wise, E., Aut Dedere Aut Judicare, p. 48.

${ }^{68}$ VCLT Art 53 “[a] peremptory norm of general international law is a norm accepted and recognized by the international community of States as a whole as a norm from which no
} 
definition of the jus cogens norm it does not exemplify it and to date, there is still no agreement as to what norms it should apply to. Most commentators seem to include as a minimum the prohibition of the use of force, racial discrimination, genocide, slavery and gross violation of the principle of self-determination. ${ }^{69}$ Others would add the prohibition of torture, norms of humanitarian law and gross human rights violations. ${ }^{70}$ Potentially, however, all fundamental values of the international legal order appear to be capable of holding a jus cogens quality. ${ }^{71}$

If the concept of jus cogens is based upon the general acceptance of fundamental and superior values within the system, ${ }^{72}$ normally all States must be seen to have a legal interest in the protection of these values. In the Barcelona Traction case, the International Court of Justice (ICJ) elaborates on the distinction between obligations of a state towards the international community and those arising vis-à-vis other states, concluding that "[b]y their very nature the former are the concern of all States. In view of the importance of the rights involved, all States can be held to have a legal interest in their protection; they are obligations erga omnes."73 This unmistakably raises one important question, decisive in this phase of the discussion, but which was left untouched by the ICJ and is still unresolved in international law and the criminal law doctrine. Does the erga omnes obligation indeed give rise to an obligation on the part of all states or is it merely denoting a right of all states to act? Here I would like to take the side of Bassiouni, arguing that an obligation erga omnes must carry with it the full implication of the word. It is fundamental to the concept of jus cogens that norms of this dignity are non-derogable and, once established, not subject to state approval or liking. Inasmuch as jus cogens norms carry with them an ancillary obligation erga omnes, these too must be non-derogable and binding on all states. Unlike violations of norms of lower rank, a violation of a jus cogens norm is not just the concern of one state but of the whole community of states.

The conclusion is as evident as it is far-reaching; according to Bassiouni, "recognising certain international crimes as jus cogens carries with it the

\footnotetext{
derogation is permitted and which can be modified only by a subsequent norm of general international law having the same character.”

${ }^{69}$ Malanczuk, P., p. 58.

${ }^{70}$ For an examination of the development of the principle, see Frowein, J. A., 'Jus Cogens' in R. Bernhardt (ed.) Encyclopedia of Public International Law 2 (Amsterdam: NorthHolland, 1997).

${ }^{71}$ Cf. Frowein, J. A., p. 67.

72 Shaw, p.117.

73 Barcelona Traction, Light and Power Company, Limited, Second Phase, Judgement, I.C.J. Reports 1970, para. 33.
} 
duty to prosecute or extradite [...] irrespective of where they were committed, by whom (including Heads of States), against what category of victims, and irrespective of the context of their occurrence (peace or war).”74 For the discipline of refugee law, this proposition should of course be of particular relevance as many of the acts and crimes of the exclusion clause are be held to be prohibited by jus cogens norms.

Having said this, it is necessary to return for a moment to the legal realities. Despite the appealing logic and structure of the argument, states practice evidently deviates from this line of argument. States do not generally act on their own accord to punish violators of jus cogens crimes such as genocide or even widespread practices of torture. Lest there is an established forum such the ICTY or ICTR states tend to stay at condemning, at best, such practices. This is even more so in individual cases of violations. When it comes to the enforcement of the principle of aut dedere aut judicare there is, in other words, a significant gap between legal expectations and legal realities. The compelling question therefore is whether the academic doctrine and legal reasoning suffice to amend this.

Personally, I find it difficult under these circumstances to establish an international positive obligation beyond the desideratum, establishing a definite, enforceable international legal obligation capable of creating state responsibility in case of non-compliance. ${ }^{75}$

\subsubsection{Conclusion}

The aim of this section has been to delineate the extent of the international legal obligation to prosecute acts and crimes relevant to Article $1 \mathrm{~F}$ of the Refugee Convention. By reference to the VCLT it was possible to rule out the possibility that such an obligation could be based directly on the object and purpose of the Refugee Convention. The applicability of the aut dedere formula in relation to Article $1 \mathrm{~F}$ crimes proved harder to establish. Despite the large number of conventions incorporating near-identical versions of the principle, there was not enough evidence to conclude that a general obligation to prosecute or extradite persons suspected of international crimes exists as a matter of customary international law. With regard to a limited number of very serious jus cogens crimes, we found, however, that there are compelling legal reasoning indicating an obligation erga omnes to prevent impunity. Yet, states have de facto been unwilling to assume such a responsibility and there is no evidence of state practice supporting the legal argument. I have therefore not seen enough evidence to support the theory

\footnotetext{
${ }^{74}$ Bassiouni, C., International Crimes, pp. 65-66.

${ }^{75}$ Cf. Bassiouni who apparently takes a less sceptical position; International Crimes, at 67, and, generally, Aut dedere aut Judicare.
} 
advanced by Bassiouni, Goodwin-Gill and others, that the principle of aut dedere aut judicare would be an obligation erga omnes. ${ }^{76}$

The suggestion by Enache-Brown and Fried, that the principle of aut dedere aut judicare would apply to all international crimes as a matter of customary international law, or the theory advanced by Bassiouni and Goodwin-Gill that the principle would, in some cases, even amount to an erga omnes obligation are, however, both extreme positions. While I have not found enough evidence to support such an obligation, I do not want to rule out that the principle may have reached customary status with regard to some conventions, or even groups of conventions.

Leaving aside the uncertain ground of customary international law there are broad areas where the principle of aut dedere aut judicare applies as a matter of convention. Many of these provisions go a long way back and are accepted norms of international law. Of course, in some situations the exact scope of the principle of aut dedere aut judicare may still be difficult to discern. There will be borderline-cases, not evidently belonging to the group of most abhorrent crimes, perhaps falling outside the principle of universal jurisdiction. For most of the acts and crimes in this group, however, the obligation to prosecute is likely to be clearly established in international law and in practice the dispute will probably remain an academic problem.

Most of the persons excluded by Article $1 \mathrm{~F}$ are likely to be excluded under $1 \mathrm{~F}$ (a). Here the legal framework is well established: Individuals excluded from refugee status due to a suspicion of crimes against humanity and war crimes must be prosecuted as a matter of conventional and customary law. ${ }^{77}$

Summarising the findings in the preceding chapters we can draw a chart on the approximate scope of the application of the universal jurisdiction with regard to $1 \mathrm{~F}$ crimes.

\footnotetext{
${ }^{76}$ See Goodwin-Gill, G. S, 'Crime in international law: Obligations erga omnes and the Duty to Prosecute', in Goodwin-Gill, G. S and Talmon, S. (eds.) The reality of International law, Essays in Honour of Ian Brownlie, (Oxford: Clarendon Press, 1999) 199224.

${ }^{77}$ No international statistics exist concerning the number of persons excluded from refugee status under $1 \mathrm{~F}$ CSR51, or on the distribution among the sub-clauses. Reports from Canada suggest that, at least in practice, a vast majority (around $80 \%$ ) of exclusion-cases are based on $1 \mathrm{~F}(\mathrm{a})$, See Rikhof, (at note 19). Whether this is a reflection of the actual situation and individual background of excludable persons, or if it has become the preferred strategy of the administrative authorities for any other reason is impossible for me to determine. At any rate, I find no reasons to believe that the distribution would be different in Germany or in Europe at large.
} 


\begin{tabular}{|c|c|c|c|}
\hline UNIVERSAL JURISDICTION & Permissive & $\begin{array}{c}\text { Mandatory } \\
\text { by convention }\end{array}$ & $\begin{array}{l}\text { Mandatory by } \\
\text { customary int'l law } \\
\text { (mandatory to non- } \\
\text { parties) }\end{array}$ \\
\hline \multicolumn{4}{|l|}{ Article 1 F (a) } \\
\hline Crime against peace & no? & no & no \\
\hline $\begin{array}{l}\text { War crimes } \\
\text { - grave breaches } \\
\text { - Hague law, Common Art. 3, APII }\end{array}$ & $\begin{array}{l}\text { Yes } \\
\text { yes (a) }\end{array}$ & $\begin{array}{c}\text { yes } \\
\text { no }\end{array}$ & $\begin{array}{l}\text { no? } \\
\text { no? }\end{array}$ \\
\hline $\begin{array}{l}\text { "Crimes against humanity" } \\
\text { - apartheid } \\
\text { - torture }\end{array}$ & $\begin{array}{l}\text { yes }(a) \\
\text { yes } \\
\text { yes }\end{array}$ & $\begin{array}{l}\text { no } \\
\text { yes } \\
\text { yes }\end{array}$ & no \\
\hline \multicolumn{4}{|l|}{ Article 1 F (b) } \\
\hline $\begin{array}{l}\text { "Common crimes" } \\
\text { - terrorism* } \\
\text { - hijacking } \\
\text { - drug-trafficking } \\
\text { - hostagetaking }\end{array}$ & $\begin{array}{l}\text { yes? } \\
\text { Yes } \\
\text { Yes } \\
\text { Yes } \\
\text { Yes }\end{array}$ & $\begin{array}{l}\text { no } \\
\text { yes } \\
\text { yes } \\
\text { yes } \\
\text { yes }\end{array}$ & $\begin{array}{c}\text { no } \\
? \\
? \\
? \\
?\end{array}$ \\
\hline \multicolumn{4}{|l|}{ Article $1 \mathrm{~F}(\mathrm{c})$} \\
\hline $\begin{array}{l}\text { Acts contrary to UN purpose and } \\
\text { principles } \\
\text { - terrorism* }\end{array}$ & Yes & yes & ? \\
\hline
\end{tabular}

(a) As a matter of customary law.

(?) Uncertainty regarding a possibly emerging customary obligation

(*) Relating to the specific acts prohibited by conventions

\subsection{International obligations of protection}

When a person is granted refugee status this carries with it not only a protection against refoulement, but a bundle of socio-economic rights such as housing (Art. 21 CSR51), public education (Art. 23 CSR51) and social security (Art. 23 CSR51). None of these of course apply to persons excluded under Article 1F. To date there is no general codification of the human rights of aliens. ${ }^{78}$ In 1985 these issues were addressed in a rather watered down declaration by the General Assembly; the Declaration on the Human Rights of Individuals Who are not Nationals of the Country in Which The Live. ${ }^{79}$ Although the instrument set out to regulate a number of aspects of the human rights of (legal) immigrants, it has had very little influence on actual state practice. ${ }^{80}$

Rejected asylum seekers' only source of rights are the general international human rights instruments, which apply without discrimination to everyone

\footnotetext{
${ }^{78}$ Fitzpatrick, J., The Human Rights of Migrants, Conference on International Legal Norms and Migration Geneva, 23-25 May 2002, at p. 2. Conference-paper available at <http://heiwww.unige.ch/conf/psio_230502/files/fitzpatrick.pdf>.

${ }^{79}$ Declaration on the Human Rights of Individuals Who are not Nationals of the Country in which They Live, G.A. res. 40/144, annex, 40 U.N. GAOR Supp. (No. 53) at 252, U.N. Doc. A/40/53 (1985).

${ }^{80}$ Fitzpatrick, J., p. 2.
} 
regardless of status, and perhaps regional or labour instruments under which they qualify due to their nationality or engagement in employment. ${ }^{81}$

To the extent that non-nationals are mentioned specifically in general human rights instruments, these provide different solutions and different levels of protection. Non-nationals are sometimes entitled to equal treatment with nationals, more often, they are subject to limitations linked to their status as an alien. In terms of socio-economic rights there are few examples of universal and absolute entitlements to state protection. ${ }^{82}$ The International Covenant on Social Economic and Cultural Rights (ICSECR66) protects the right to education, to health and to housing but these provisions are vaguely formulated and derogable. ${ }^{83}$ Some human rights of course are absolute and non-derogable. The rights to life (ICCPR66 Art. 6), the prohibition against torture (ICCPR66 Art. 7) and the prohibition against slavery (ICCPR66 Art. 8) among others, apply to all people without distinction and irrespective of war or public emergency. These rules therefore provide a lowest threshold for the treatment of excluded individuals. Over that level however, people can only claim the right to equal treatment, a right, which is derogable.

In summary, without the protection of the Refugee Convention, the social well-being of these individuals is the prerogative of the sovereign state. Only at a very lowest level, where state actions could amount to torture or cruel or inhuman treatment or punishment, would a person be protected as a matter of international law.

On the regional level there have been some attempts to establish standards of socio-economic rights. Again, however, the only European instrument introducing explicit and enforceable social and economic rights, the EU Qualification Directive, will not be applicable to excluded individuals. ${ }^{84}$

If the only legal obligation a country has in regard of excluded individuals is in effect not to subject them to inhuman or degrading treatment, the scope of permitted action is considerably wide. In a subsequent chapter I shall

\footnotetext{
${ }^{81}$ Dent, J. A., Research paper on the social and economic rights of non-nationals in Europe, Commissioned by the European Council on Refugees and Exiles (ECRE). At p. 128. Available at <http://www.ecre.org/research/socecon.doc $>$.

${ }^{82}$ Fitzpatrick, J. p. 10.

${ }^{83}$ For an excellent report on rights relevant to non-nationals see John Dents research paper (note 81).

${ }^{84}$ Proposal for a Council Directive on minimum standards for the qualification and status of third country nationals and stateless persons as refugees or as persons who otherwise need international protection, Brussels, 12.9.2001, COM (2001)510 final, (hereinafter the Qualification Directive).
} 
therefore leave the legal issue aside, examining instead how a country like Germany has chosen to deal with this freedom. 


\section{The European Union}

\section{1 "An area of freedom, security and justice"}

With the entry into force of the Amsterdam Treaty on 1 May 1999 the area of asylum and migration became a part of the European Community legal framework. ${ }^{85}$ The Union has since then adopted a comprehensive approach, dealing with these issues as part of the larger initiative to create "an area of freedom, security and justice" in Europe. The long-term objective of the European asylum legislation is to establish the Common European Asylum System (CEAS) with a common asylum procedure and a uniform status, valid throughout the Union. Although the CEAS, as the whole of the Tampere process, may have some human rights aspects to it, the harmonisation of asylum policies in the EU has also been necessary to curb some of the side effect of an internal market without inner borders. Hence, the process, which began in 1997 with the entry into force of the Dublin Convention, was aimed at preventing asylum seekers from being shuffled around by European states ("refugees in orbit") as well as at restraining secondary movement by eliminating the rationale for "asylum shopping". The Dublin Convention was only partly successful. For the system to run smoothly it was necessary not only to adopt a convention determining the state responsible for examining an asylum application but also to establish a common procedure for the establishing of refugee status and minimum standards on the reception of asylum applicants and for the qualification of persons as refugees. At the Tampere summit, the Heads of State or Government agreed that on the road to building a common European asylum system, this first set of standards and measures must be adopted by May 2004.

\subsection{The exclusion clause of the Qualification Directive}

In order to achieve the CEAS it has been found necessary to establish a common understanding of who qualifies for international protection both under the 1951 Convention and for the EU-wide protection scheme. For, even though all EU member states are parties to the 1951 Convention, state practice still varies considerably with regard both to the refugee

\footnotetext{
${ }^{85}$ See TITLE IV — Visas, asylum, immigration and other policies related to free movement of persons, in the consolidated version of the Treaty establishing the European Community (TEC), Official Journal C 325 of 24 December 2002.
} 
determination and to subsidiary protection. When it comes to the terms of residence, employment opportunities etc, there has, until now, not been any harmonisation at all. Hence, the Qualification Directive, which is still being negotiated, will play a central role in the CEAS project. $^{86}$ It not only provides a common interpretation of who should be awarded refugee status and subsidiary protection, but it also establishes a minimum standard of socio-economic protection of this group. In its explanatory memorandum, the Commission confirms the objectives to "limit secondary movement of applicants for international protection" while, at the same time, guaranteeing a "high level of protection of those genuinely in need for it" and prevent abusive asylum applications. ${ }^{87}$

The Directive establishes a number of important socio-economic rights to individuals granted international protection and has been said to "fully comply with or exceed the standards set in the relevant provisions of the Geneva Convention". ${ }^{88}$ With regard to rights awarded to individuals under subsidiary protection, the level of the rights established by the Directive is of special importance as there are no comparable international obligations (see preceding chapter).

The Qualification Directive incorporates an exclusion clause, which does not replicate the precise wording of Article $1 \mathrm{~F}$ of the 1951 Convention but is nonetheless clearly modelled on its provision. ${ }^{89}$ The UNHCR has found no reason to object to the clarifying elements but has rather welcomed what it considers to be a "codification [...] of certain fundamental principles of accepted doctrine and State practice with respect to exclusion”, ${ }^{90}$

Since the Tampere Conclusions, the EU has stressed its intention of basing the common system of asylum on the "full and inclusive application" of the Refugee Convention. ${ }^{91}$ This assertion is reiterated in the Qualification Directive which, in its preamble, states that "[t]he Geneva Convention and

\footnotetext{
${ }^{86}$ Following negotiations in the Council (JHA) the proposal has been amended several times. Although not officially released, many of the drafts are available on the Internet. In this study, all references to the Directive are to the final proposal, COM (2001)510 final, which is the last version publicly available.

${ }^{87}$ Qualification Directive, Explanatory Memorandum, p. 3.

${ }^{88}$ Battjes, H., 'A balance between fairness and Efficiency? The Directive on International Protection and the Dublin Regulation', European Journal of Migration Law, 4 (2002), 159192.

${ }^{89}$ See Supplement B.

${ }^{90}$ UNHCR's Observations on the European Commission's proposal for a Council Directive on minimum standards for the qualification and status of third country nationals and stateless persons as refugees or as persons who otherwise need international protection. November 2001. P 10.

${ }^{91}$ Tampere European Council - Presidency Conclusions 16/10/1999 - Press: 0 Nr: 200/1/99. At 13.
} 
Protocol provide the cornerstone of the international legal regime for the protection of refugees" (paragraph 3). The supremacy of the CSR51 is emphasised again in Article 18 stating that "[t]he rules laid down in this Chapter shall be without prejudice to the rights laid down in the Geneva Convention". ${ }^{2}$

The Qualification Directive regulates not only the determination of refugee status but also the eligibility for subsidiary protection. Combining the interpretation of who is a refugee and the definition of people otherwise in need of international protection is, with the words of the European Council on Refugees and Exiles (ECRE) "sensible" and may well "be a recognition of obligations under human rights law". ${ }^{93}$ Subsidiary protection shall be granted to those individuals who risk "serious and unjustified harm" such as death penalty or execution, torture or inhuman or degrading treatment or punishment or "a threat to his or her life, safety or freedom as a result of indiscriminate violence arising in situations of armed conflict, or as a result of systematic or generalised violations of their human rights." 94

The entitlement to subsidiary protection, however, is subject to the same exclusion clause as the refugee status. A person who is excluded from refugee status based on the suspicion of a serious crime will consequently also be excluded from the subsidiary protection established by the Directive, notwithstanding a risk of torture or other serious harm. It should be made clear however, that this does not mean that excluded individuals would also be withheld protection against refoulement. The Directive neither can nor attempts to prejudice internationally binding conventions. There is no international obligation to ensure a status of subsidiary protection with a particular level of social and economic rights; states are consequently free to determine their own criteria for the entitlement, as well as exclusion, from

\footnotetext{
${ }^{92}$ Art. 18 Qualification Directive, formally, this statement is of course superfluous. Despite the supremacy of EC law over member states' domestic legal system, the European Union is unable to change the content of international law. The EC confession to the Refugee Convention may however have much practical importance. While, under the Refugee Convention, states are bound to its provisions, their interpretation of the Convention has, as mentioned earlier, varied considerably. Within the international community of sovereign states, states parties have been able to adopt and exert their own interpretation without the reviewing of any international enforcement body. The Qualification Directive however sets out to adopt a common interpretation of the Convention which is legally binding on all EC member states and, more than that, which can, at least in theory, be enforced by the European Court of Justice. Hence a consistent adoption of the "full and inclusive" interpretation of the Refugee Convention is of great importance.

${ }_{93}$ ECRE, Comments from the European Council on Refugees and Exiles on the proposal for a Council Directive on minimum standards for the qualification and status of third country nationals and stateless persons as refugees or persons who otherwise need international protection. March 2002. Available at <http://www.ecre.org/statements/status comms.shtml>.

${ }^{94}$ Qualification Directive, Article 15.
} 
such a status. Hence, the establishment of a common status of subsidiary protection within the EU can only affect the rights of this group, not their protection from refoulement. In other words, a person excluded from both refugee-status (Art. 14) and subsidiary protection (Art. 17) but who falls under the human rights bar to removal, will still be entitled to protection against refoulement. Their status, however, remains unresolved by the Directive.

Whether in practice the proceedings will always be this clear-cut is impossible to establish in this context. While the directive is very explicit in excluding people from international protection, it makes only a brief referral to the prohibition of refoulement and does not further discuss the circumstances. Amnesty International has criticised this, recommending the Commission to add to Article 19 (a) reference to Member States' international obligations and the absolute character of the non-refoulement principle embodied in Article 3 of the CAT84, Article 3 of ECHR50, or Article 7 of the ICCPR66. ${ }^{95}$

In summary, among EU Member States, anyone suspected of such serious crimes referred to in Article $1 \mathrm{~F}$ will neither be entitled to a status as refugee nor as 'a person eligible for subsidiary protection'. Due to their international legal obligations, States are nonetheless obliged to grant these individuals some kind of leave to remain in the country. The character of this status, however, not to mention its socio-economic standards, remains unregulated within the context of the European Union.

\footnotetext{
${ }^{95}$ Amnesty International's Comments on the Commission's Proposal for a Council Directive on Minimum Standards for the Qualification and Status of Third Country National and Stateless Persons as Refugees or as Persons Who Are Otherwise in Need of International Protection, COM (2001)510 final,+ 2 October 2002. At p. 9.
} 


\section{Germany}

\subsection{Introduction}

In the preceding chapters I have examined the international and European framework with regard to the exclusion clause and the treatment of individuals excluded from refugee status. It was clear from the start that the Refugee Convention would endorse the prosecution of these individuals. I have established, however, that with regard to most of the crimes covered by Article $1 \mathrm{~F}$, states also have an explicit obligation to prosecute as a matter of conventional law. With regard to some crimes, such as hijacking, there are good reasons to believe that a parallel obligation may have crystallised as a matter of customary international law. Furthermore, crimes relevant in this connection, almost always, give rise to (permissive) universal jurisdiction, giving states a legal right to prosecute any suspect of such serious crimes under their own jurisdiction.

The preceding examination also showed that when a person who is excluded from refugee status is not prosecuted or is released from custody, there is no regulated status determining the rights and obligations of such a person visà-vis the state. On a very basic level, the prohibition of torture or cruel or inhuman treatment prohibits the worst kind of treatment. Other than that, there are no substantive, minimum norms of economic and social rights of non-removable individuals but states are free to proceed with this group, as they see fit.

In chapter 4, I shall analyse how a European country, Germany, has chosen to deal with the issues of exclusion and prosecution in connection with asylum seekers. In the first section I will briefly describe the development and distinct features of the German asylum-policy, hoping that this will help explaining some of the problematic issues and evident shortcomings of the present regulation. Second, I shall attend to the recent implementation of the exclusion clause in German refugee law and its adherence to international law. Third, I will examine German criminal law with the aim of determining whether or not Germany fulfils the obligation to prosecute that was established in chapter 2. Finally I shall look at the post-exclusion phase, focusing on socio-economic rights and elaborate on the overall suitability of the practice, in the light of both the object and purpose of the Refugee Convention and of the German motives for implementing the exclusion clause. 


\subsection{Framing the German asylum policy}

Following the experiences of World War II, a unique provision was inserted in the German Constitution. With no precedence, and no counterpart in the world, the German Constitution, adopted 1949 in the Federal Republic, provided a right not only to "seek and enjoy" asylum (cf. UDHR Art. 14) ${ }^{96}$ but an actual right for "persons persecuted on political grounds" to be granted asylum in the new-founded state. ${ }^{97}$ Anyone claiming political persecution, no matter how convincing the facts, had the constitutional right of entry, complemented by full access to judicial review, including access to the German Constitutional Court (BVerfG) in case of a rejection. Combined, this of course signified a considerable, albeit self-imposed, restriction of the fundamental notion of the territorial sovereignty of a state. It also laid the ground for an asylum policy, which, for the next four decades would make Germany Europe's "prime target for the asylum strategy of immigration." 98 That the German right to asylum survived intact for so many years should probably be explained by the ideological symbolism connected to the constitutional right of political asylum. This fact, reportedly employed to its limits by asylum advocates, may well have contributed to "elevat[ing] Article 16 (a) into a quasi-sacred taboo". ${ }^{99}$ It is also, I would argue, one of the reasons why until today, Germany has not fully adopted the 1951 Refugee Convention.

In 1973, following the oil crisis, and as a part of its new zero-immigration policy, Germany put a stop to the recruitment of new guest workers (Anwerbestop). If this was an attempt to restrict the number of new entries, the approach was hardly successful. Having made asylum the only legal avenue for immigration, the number of asylum seekers multiplied after the Anwerbestop. ${ }^{100}$ To curb the flow of asylum seekers, Germany then turned to the tactics of social deterrence and the streamlining of the legal process, including a fast-track procedure for "obviously unfounded" applications. Still, however, the constitutional right of asylum was left untouched. By the end of the 80 s, Germany was receiving over $60 \%$ of the total share of the

\footnotetext{
${ }^{96}$ The meaning may not be obvious. Article 14 of the UDHR does not entail an individual right of asylum. Rather, it is a manifestation of the right of any sovereign state to grant asylum to foreign nationals. Göbel-Zimmerman, Ralph, Asyl- und Flüchtlingsrecht NJWSchriften 41/2, (München: C.H. Beck, 1999), p. 14.

97 "Politisch Verfolgte genießen Asylrecht”, original Article 16 Abs. 2 S. 2 Grundgesetz für die Bundesrepublik Deutschland [hereinafter Grundgesetz, GG] vom 23. Mai 1949 (BGBI. I S.1). Today found in Article 16a (1), the phrase is qualified by 16a (2) - 16a (5).

${ }^{98}$ Joppke, C., 'Asylum and State Sovereignty: A Comparison between the United States, Germany, and Britain', in Joppke, C. (ed.) Challenge to the Nation State, (Oxford: Oxford University Press, 1998). p. 122.

${ }_{99}$ Ibid. p. 123.

${ }^{100}$ Ibid. p. 125.
} 
asylum seekers to Western Europe, adding to a large number of ethnic Germans (Aussiedler) and, after the unification, resettlers (Übersiedler). ${ }^{101}$

Especially in the eastern parts, the local population had problems accepting the massive increase of foreigners. ${ }^{102}$ The societal stress, spurred by unemployment and shortage of housing, eventually lead to unrest. ${ }^{103}$

\subsubsection{EU harmonisation and change of policies}

In the negotiations on the Schengen and Dublin treaties, Germany made several suggestions with the intent to co-ordinate and spread the burden of asylum admissions. ${ }^{104}$ The rest of Europe, however, having little to win by a change, turned down the proposals. This presented Germany with a perplexing scenario. Following the established interpretation of Article 16 (a) GG, Germany would have to warrant entry and full access to judicial review to any asylum seeker, including those whose asylum-claims had already been investigated and rejected by another member state. It seemed at this time that Germany would end up, with the words of Interior Minister Wolfgang Schäuble, as the "reserve asylum country of Europe", ${ }^{105}$ receiving asylum applications from all other member states without itself being able to benefit from the distributory mechanisms.

Faced with the reality of the Schengen/Dublin framework, Article 16 (a) was eventually amended. ${ }^{106}$ The constitutional right to political asylum was not abandoned but subjected to massive restrictions. People arriving from "safe third countries", were completely excluded from the possibility to seek asylum according to Article 16 (a) and denied entry or, if found on the territory, immediately expelled. ${ }^{107}$ A second group of people, coming from a "safe country of origin", is considered prima facie not politically persecuted. Their applications are handled in a fast-track procedure,

\footnotetext{
${ }^{101}$ Joppke, C., p. 126.

${ }^{102}$ In accordance with the agreement of the reunification treaty of 31 August 1990, 20\% of the total number of asylum seekers were allocated to the new Bundesländer.

${ }^{103}$ Members of the local population in the Eastern German towns of Hoyerswerda and Rostock-Lichtenhagen provided a frightful example of the gravity of the situation. The two towns became known over night when masses of locals were filmed cheering German neonazis and skinheads torching asylum centres, seriously risking the lives of hundreds. ${ }^{104}$ Joppke, C., pp. 128-129. In 1991 Germany also campaigned to delegate national competencies for a unified asylum law and procedure to the Commission.

${ }^{105}$ Joppke, C., p. 129.

106 The necessary 2/3 majority was reached in a compromise between the CDU/CSUgovernment and the opposition (SPD and FDP, not Bündnis 90). For the debate and negotiating process, see Zimmermann, A., Das neue Grundrecht auf Asyl. Verfassungs- und völkerrechtliche Grenzen und Voraussetzungen, (Berlin: Springer, 1994), p. 23-38.

${ }^{107}$ Apart from member states of the European Union, additional states are to be defined "safe" after approval of the Bundesrat. Currently this is the case of Norway, Poland, Schweiz and the Czech Republic (Anlage I zu § 26a AsylVfG).
} 
generally resulting in the rejection as "obviously unfounded". The last provision introduced the "airport regulation". Applicants arriving at an airport either from a safe country of origin or without a valid passport are subject to the fast-track recognition procedure in "extraterritorial airport space". Seen together, the three clauses today effectively dismantle the original right to asylum for politically persecuted. Even if all politically persecuted persons from non-EU/non-safe countries still have a right to asylum, their successful asylum application is depending on their ability to find a way to arrive by air or ship; with valid papers and without passing "safe" states along the way, to actually claim it. ${ }^{108}$

\subsubsection{The position of the Refugee Convention in German law}

Germany was one of the first six states to ratify the CSR51 in 1951. In 1953 it was adopted as German law by a decision of the German Bundestag (Zustimmungsgesetz), but its provisions were never directly incorporated. ${ }^{109}$ Because refugee law in Germany was intrinsically connected to the Constitutional right to asylum, the Geneva framework seemed to have attracted less interest. The common belief seems to have been that the German right to asylum was in all parts equal, if not superior to the refugee protection of the Convention. ${ }^{110}$ Nevertheless, in 1965 Article 16 (a) GG was complemented with a provision of non-refoulement corresponding to Article 33(1) the Refugee Convention. ${ }^{111}$

\footnotetext{
${ }^{108}$ The amendment to Article 16 was not only a fierce restriction of a previously uniquely liberal provision, it also gave rise to serious doubts of whether Germany would not thereby be in breach if its international obligations. Critics especially pointed out that lists of "safe states" could not be, in practice, absolute in order to avoid a violation of the ECHR (Art. 3 and 13) and the CSR51 (Art. 33). However, "[1]änderlisten mit der Möglichkeit einer Entkräftung der Vermutung der Verfolgungssicherheit sind dagegen als zulässig anzusehen.” Frowein, J. A. \& Zimmermann, A., Der völkerrechtliche Rahmen für die Reform des deutschen Asylrechts (Köln: Bundesanzeiger, 1993), p. 57. On the compliance of 16 (a) GG to international law generally, see Zimmermann, A., Das neue Grundrecht auf Asyl. Fear that the amendment would violate the German Constitution (especially in regard of the German Rechtsstaatsprincip) was settled by the BVerfG in a judgement dated 14 May 1996.

${ }^{109} \mathrm{BGBl}$. II 1953 S. 559; BGBl. 1954 S. 619. In accordance with Article 19 (4) GG a negative decision can therefore be appealed in the court just as a decision under the constitutional right to asylum. In contradistinction to Article 16a, however, it does not have status of basic law and can be abolished by a single majority vote in the parliament.

${ }^{110}$ See e.g. Zink, K. F., Das Asylrecht in der Bundesrepublik Deutschland nach dem Abkommen vom 28. Juli 1951 über die Rechtsstellung der Flüchtlinge unter besonderer Berücksichtigung der Rechtsprechung der Verwaltungsgerichte, (Nürnberg: Staudacher. 1962), chapter. 5. I shall refrain from further discussing this issue here. It should be clear however that the German refusal to grant asylum to individuals persecuted by non-state actors, refugees sur place, and gender-specific persecution, clearly diverts from UNHCR recommendations as well as from general state practice.

${ }^{111}$ Art. 14 (1) AuslG 1965. Article 51(1) of the AuslG 1990.
} 
An alien may not be expelled to a state in which his life or freedom would be threatened on account of his race, religion, nationality, membership in a particular social group or political opinion. ${ }^{112}$

When the constitutional right to asylum was gradually deconstructed in the 1990s this article simultaneously gained importance. ${ }^{113}$ At the same time there were renewed calls for the full adoption of the refugee definition of Article 1A; such proposals, however, never found a majority. ${ }^{114}$ Hence, although the Refugee Convention can be evoked in court, the German Aliens Act, as well as the Asylum Procedure Act (AsylVfG) still lack a definition of who is a refugee implementing the inclusion clause of the Refugee Convention. It has been argued that after the second asylum compromise in 1992, Article 51(1) indirectly became the German norm uphold the international obligations of the 1951 Refugee Convention. ${ }^{115}$

\subsection{German asylum law today}

\subsubsection{The German Aliens Act (AuslG).}

The first German Ausländergesetz from 1965 was characterised by its numerous, vaguely defined legal concepts and a number of blanket clauses that provided the administration with a considerable power of discretion. This state of affairs has been questioned for its incompatibility with basic principles of the rule of law, ${ }^{116}$ it did, however, enable a highly flexible application of the law and asylum policy. In the early 1970s it handled the massive stream of migrant workers; twenty years later it was used - albeit less successfully - to stem the flow of asylum seekers from new war spots. In the 1965 system there were only two different resident permits: Aufenthaltserlaubnis and Aufenthaltsberechtigung. With the 1990 amendment, two further statuses were introduced, making room for a far more differentiated but also a more complicated system. It has therefore been

\footnotetext{
112 "Ein Ausländer, darf nicht in einen Staat abgeschoben werden, in dem sein Leben oder seine Freiheit wegen seiner Rasse, Religion, Staatsangehörigkeit, seiner Zugehörigkeit zu einer bestimmten sozialen Gruppe oder wegen einer politischen Überzeugung bedroht ist”, (translation by the author).

${ }^{113}$ Fritz. R., (ed.) Gemeinschaftskommentar zum Ausländerrecht (AuslR), (Neuwied: Luchterhand, 1995). September 1996, II-§ 51 at para 8.

${ }^{114}$ The arguments against such an implementation has varied. Preceding the 1990 amendment to AuslG a proposal by the SPD to fully incorporate the Geneva refugee definition in AsylVfG was turned down. The reason given by the Ministry of the Interior (BMI) to was to avoid "causing irritation in the administrative courts." As quoted in Fritz, R., AuslR II § 51 at 10.

${ }^{115}$ Fritz, R., AuslR II § 51 at para 13.

${ }^{116}$ See e.g. Renner, G., 'Aufenthaltsrechtliche Grundlagen für Arbeitserlaubnis und Sozialleistungen’, Zeitschrift für Ausländerrecht, 1 (1995) p. 13.
} 
questioned whether the desired clarity of law has not been obstructed by inscrutability. ${ }^{117}$

\subsubsection{Residence permits}

The residence status plays an important role in the German asylum system not least for its role in establishing secondary rights such as working permits, social security benefits etc.

Presently four different legal titles confer one or the other type of residence permits (Aufenthaltstitel). ${ }^{118}$ Asylum seekers who are granted asylum on the basis of Article 16 (a), the so called "grosses Asyl” ("big asylum”), will receive an Aufenthaltserlaubnis (Art. 68 AsylVfG), which is an unlimited residence permit. After eight years, the alien can, if certain provisions regarding social security contributions are met, apply for the most farreaching of all residence permits - the Aufenthaltsberechtigung (Art. 27 AuslG). Those who do not meet the conditions of Article 16 (a) but fulfil the requirements of the Refugee Convention will be awarded the "kleines Asyl" (“small asylum”) and be granted a 'permission to stay' (Aufenthaltsbefugnis Art. 70 AsylVfG). This is the least far-reaching of all residence permits and is usually a temporary solution where humanitarian and/or practical reasons prevent the return of an alien or un-successful asylum seeker.

People who are not entitled to any of these permits but who can not be expelled for one or the another reason may receive a so-called Duldung, or “toleration". This is, strictly speaking, not a residence title, but a legal arrangement that allows that individual to remain on German territory for a limited period of time.

\subsection{The German implementation of Article 1F}

\subsubsection{The "terrorism caveat"}

As recently as in 1983, the German federal administrative court (BVerwG), stressed that the constitutional right to asylum did not know any restrictions equivalent to the Articles $1 \mathrm{~F}, 1 \mathrm{C}$ or 33(2) CSR51. ${ }^{119}$ During the $1960 \mathrm{~s}, 70 \mathrm{~s}$ and 80s Germany would offer refuge both to those responsible of the

\footnotetext{
117 "Rechts- und Erwartungssicherheit”. Explanatory note by the Bundesregierung, BT-Drs. 11/6321 p. 40. As cited in Renner, G., 'Aufenthaltsrechtliche Grundlagen', p. 13.

${ }^{118}$ Three of these titles are relevant with regard to asylum seekers, the fourth (Aufenthaltsbewilligung) may be obtained by foreign students, nationals of EU/EES member states etc.

${ }^{119}$ BverfGE 68, 171= EZAR 200 Nr. 9.
} 
Turkish military coup and the henchmen of the Greek junta. ${ }^{120}$ The German asylum legislation was, however, not inherently exempt from every restriction. In 1989, the German constitutional court decided that the persecution of individuals responsible for violent political acts did not give rise to a right to political asylum according to the Grundgesetz. The case, which regarded a Sri Lankan Tamil, was to set an example for what became know as the "terrorism caveat" or Terrorismusvorbehalt. ${ }^{121}$

This "terrorism caveat" has been extensively developed by the German courts and has shaped a case law, which is separate from the international development and UNHCR recommendations. Courts have emphasised the ultima ratio character of the provision. The prosecution must show that a concrete risk of renewed criminal behaviour exists. ${ }^{122}$ By the same logic it is not sufficient to establish a general risk of recidivism, but the foreseen crime must, in itself, amount to a crime of the relevant severity.

With the 1990 amendment to the Aliens Act, ${ }^{123}$ the terrorism caveat was confirmed by Article 51(3). It states, in essence, that the protection against refoulement shall not apply when an alien poses a security-threat to Germany or has been convicted for a particularly severe crime to no less than three years' imprisonment and is therefor a danger to the society. ${ }^{124}$

The provision is near identical with Article 33(2) of the CSR51; materially it only provides a more precise definition of the terms of expulsion by introducing the three-year limit. It may be interesting to note that, while Article 33 CSR51 speaks only of "refugees" the corresponding German provisions of both 51(1) and 51(3) speak of "alien”. According to Article 1 Abs. 2 AuslG an alien is "anyone who is not German in the sense of Art. 116 (1) GG.” It may appear odd then, judging from the wording, that the German exception to the prohibition of refoulement extends to all foreign nationals: refugees who have been granted asylum as well as asylum seekers or non-refugees. In practice the difference is without importance. Because of the lack of another definition, Article 51 (1) is effectively the German Article determining refugee status. Hence, the protection only covers aliens who are, in fact, refugees by definition. Since only refugees (including individuals with the right to asylum according to 16 (a) GG) are protected from refoulement in the Article, only refugees can be exempted.

\footnotetext{
${ }^{120}$ Renner, G,. 'Terrorismusbekämpfung und Schutzsuchende’, Zeitschrift für Ausländerrecht, 2 (2003) 53-59.

${ }^{121}$ BverfGE 80, 315 = EZAR 201 Nr. 20.

${ }^{122}$ VGH BW, B. v.5. 10. 1994 - 11 S 1202/94 -, VBlBW 1994 Ls 522/199.

${ }^{123}$ Gesetz zur Neuregelung des Ausländerrechts vom 9. 7. 1990 (BGBl. I. S. 1354).

${ }^{124}$ For the German text see Supplement C.
} 
The more interesting question then is at what stage of the refugee determination procedure the possible removal/exclusion becomes relevant. Article 33(2) speaks of "refugees", that is people who meet the criteria of Article 1A. The German equivalent to Article 33(2) (art. 51(3)) is adjoined by a second Article ( $§ 52$ AuslG), which in cases where 51(3) applies allows the expulsion of asylum seekers during an ongoing refugee determination procedure. ${ }^{125}$ As long as the decision on refugee status is pending the expulsion of the individual is not mandatory. As indicated by the wording (kann) of Article 52, the responsible authority has a certain margin of discretion as to whether the procedure should be allowed to continue or if the asylum seeker should be expelled before the completion. ${ }^{126}$ This raises two issues: the confusion of concepts and the question of inclusion before exclusion.

Following the structure of the international refugee law to which Germany is bound, a person can either:

- be granted formal status as a refugee (according to Art. 1A) and thereafter, if 33(2) is met, be expelled, or

- be found meeting the criteria of Article $1 \mathrm{~A}$ but be excluded from refugee status in the initial refugee determination procedure because of serious crimes. Such a person can also be expelled.

In its Aliens Act however, Germany mixes these concept. It excludes people from refugee status not on the grounds for exclusion (Article 1F) but on the grounds for expulsion (33(2)). This confusion of legal definitions may not seem very significant but may be indicative of a pattern where Germany is unwilling to incorporate international refugee law in a systematic fashion and thereby may risk causing serious problems as a consequence.

Since its adoption in 1990 the Aliens Act has been subject to two major revisions; the Terrorismusbekämpfungsgesetz and the Zuwanderungs-

\footnotetext{
125 “In den Fällen des § 51 Abs. 3 kann einem Ausländer, der einen Asylantrag gestellt hat, abweichend von den Vorschriften des Asylverfahrensgesetses die Abschiebung angedroht und diese durchgeführt werden." The Asylverfahrensgesetz contains a set of rules which otherwise provides asylum seeker with a temporary protection from expulsion for the time of the determination procedure.

${ }^{126}$ The responsibility for carrying out the decision rests by the administrative authorities. In the interest of safeguarding the interests of the asylum seeker (who will most likely be expelled if the conditions of 51.3 are met) as well as a coherent practice the administrative authorities shall confer with the Federal Office for Recognition of Foreign Refugees (BAFL) Bundesamt für die Anerkennung ausländischer Flüchtlinge. See the commentaries to the Alien Act in Fritz, Gemeinschaftskommentar.
} 
gesetz, ${ }^{127}$ none of which have amended the systematic errors of the provision. If anything, the introduction of the Terrorismusbekämpfungsgesetz, has only brought Germany further on a collision course with the Refugee Convention.

\subsubsection{The introduction of the exclusion clause by the Terrorismusbekämpfungsgesetz}

With the entry into force of the new Terrorismusbekämpfungsgesetz on 1 January 2002, Germany finally introduced Article $1 \mathrm{~F}$ in its asylum law. The law was the second part of a comprehensive "anti-terror package" which was adopted with direct reference to the events of 11 September. Even so, the German adoption of Article 1F could not have waited much longer. As a member of the European Union, lacking the Danish/British/Irish opt-out clause in the area of asylum- and migration law, Germany was bound to implement the European asylum policy, with its principled adherence to the Geneva framework.

The purpose of introducing the exclusion clause was, to cite the legal motives, "to facilitate a limitation of the protection against expulsion in cases where it can merely be assumed that the corresponding crimes have been committed, while taking into account the legal principles of Article 1F." ${ }^{128}$ The link to the prevention of terrorism cannot be mistaken. With the amendment, the federal government further intended to implement the calls by the UN Security Council (Res. 1269 and Res.1373) not to grant refugee status to terrorists. It was the Government opinion that introducing Article $1 \mathrm{~F}$ would make Germany less interesting as a "safe haven for internationally operating terrorist-networks". ${ }^{129}$ The way of implementation, however, is problematic.

Not having implemented the inclusion clause of the Refugee Convention, the exclusion clause was incorporated in connection with the German equivalent to Article 33 (1) CSR51. As illustrated in the preceding chapter,

\footnotetext{
${ }^{127}$ Terrorismusbekämpfungsgesetz vom 9.1.2002 (BGBl. I S. 361), Gesetz zur Steuerung und Begrenzung der Zuwanderung und zur Regelung ders Aufenthaltsund der Integration von Unionsbürgern und Ausländern (Zuwanderungsgesetz) vom 20. Juni 2002 (BGBl. I S. 1946). Due to a dramatic decision by the Constitutional Court the Zuwanderungsgesetz was overturned on formal ground on 18 December 2002 and never entered into force.

${ }^{128}$ Deutscher Dundestag -14. Wahlperiode, Drucksache 14/7386, p. 57. (Translation by this author.) "[U]nter Berücksichtigung des Rechtsgedankens des Artikels 1 F [...] eine Einschränkung des Abschiebungsschutzes bereits dann [zu] ermöglichen, wenn nur anzunehmen ist, dass entsprechende Taten begangen wurden“.

${ }^{129}$ Deutscher Dundestag -14. Wahlperiode, Drucksache 14/7386, p. 57. "Ruheraum für international agierende terroristische Netzwerke”. (Translation by this author.)
} 
this article is qualified by the Terrorismusvorbehalt, exempting certain criminals from protection against refoulement. The implementation of Article $1 \mathrm{~F}$ was reached by simply adding the contents of the exclusion clause to this provision (see Supplement C). As we shall see, although the German exclusion clause is a literal translation of Article $1 \mathrm{~F}$ its placement next to the equivalent to Article 33(2) gives it the function of expanding the scope of Article 33(2). Considering the legal motives as well as the placement of the provision one must assume that the German legislator was not unaware of this outcome.

The amendment is remarkable also in as much as Germany has now introduced the exclusion clause of Article 1 CSR51 without the inclusion clause. Despite the recommendations of UNHCR, Amnesty International and various other NGOs, Germany did not take the opportunity of the Terrorismusbekämpfungsgesetz (or the Zuwanderungsgesetz) to incorporate Article 1 in its entirety. ${ }^{130}$

As often stressed by UNHCR the inclusion clause of Article $1 \mathrm{~A}$ and the exclusion clause of $1 \mathrm{~F}$ are both intrinsic parts of the refugee determination process. Individuals to whom Article 1F apply, have been found needing international protection but are nevertheless excluded from refugee status due to their participation in acts ultimately irreconcilable with core values of equity and humanity. Individuals, to whom 33(2) apply, on the other hand, are not deprived of their status as a convention refugee. They remain refugees as long as they meet the $1 \mathrm{~A}$ criteria, albeit without the enjoyment of the most important of their protective rights: the protection against refoulement. Both of these decisions, to include or exclude, are likely to have profound implications. UNHCR has therefore, on numerous occasions stressed the absolute necessity of a restrictive interpretation and the consideration of all available facts. This dubious implementation, hence, may risk violating Germany's international obligations in the field of refugee protection.

Although these objections may, at first, seem to be merely a legal technicality the confusion of concepts points at a potentially far more critical confusion of objectives. As demonstrated in section 2.1.1, contrary to Article 33(2), Article 1F was not primarily conceived to protect matters of state security but of the refugee system as a whole. When a state incorporates Article $1 \mathrm{~F}$ as an extension to 33(2) it, it will depend on judges

\footnotetext{
${ }^{130}$ UNHCR, UNHCR-Stellungnahme: Innere Sicherheit und Flüchtingschutz, 23. October 2001; UNHCR-Stellungnahme zur Anhörung “Zuwanderungsgesetz” des Innenausschusses des Deutschen Bundestages am 16. Januar 2002.
} 
whether the correct interpretation is eventually made. I see a risk here that the exclusion clause may be interpreted merely as an extension to the Terrorismusvorbehalt. Making eligibility of protection as a refugee a matter of national security, the protective scope of the provision may be unduefully limited as a result.

\subsubsection{A risk of unlawful refoulement}

The different objectives of Article $1 \mathrm{~F}$ and 33(2) are reflected in the requirements of the respective provisions. Individuals with an established status as a refugee have been endowed with a particularly strong protection against expulsion. Only where a refugee is a "danger to the security of the country" or "constitutes a danger to the community" can he or she lose the protection against refoulement. However, since the aim, as well as focus of Article 33(2) is to protect the security of the state, even a conviction for a particularly grave crime should not lead to refoulement if, for some reason, that person does not, or no longer, pose a security-threat to the country. ${ }^{131}$ Consequently, expulsion according to Article 33(2) always requires that an analysis is carried out establishing a current or future danger to the country or community. ${ }^{132}$ When it comes to exclusion according to Article $1 \mathrm{~F}$ the situation is very different. The provision does not affect refugees and, more interestingly in this context, Article $1 \mathrm{~F}$ is unconditional. If a person meets the criteria of the provision, it is immaterial whether he or she may endanger national security or is completely harmless. The main purpose of the Article is not primarily to protect a certain state but to exclude individuals unworthy of enjoying the protection as a refugee. Therefore, the criteria for exclusion and expulsion differ. In relation to exclusion a state needs only to establish "serious reasons for considering" that a person has committed a certain crime, while the expulsion of a refugee demands that that person "ha[s] been convicted by a final judgement" and "constitutes a danger to the community. ${ }^{133}$ On the other hand, the exclusion clause is applicable only with regard to certain types of crimes or acts while a decision of expulsion can be based on any "serious crime".

\footnotetext{
${ }^{131}$ Grahl-Madsen, A., Commentary on the Refugee Convention 1951, Vol. 3, articles 31-37 (Geneva, 1963). Art. 33 (10).

${ }^{132}$ The same concept is known in the Terrorismusvorbehalt as the "Wiederholungsgefahr".

${ }^{133}$ The standard of evidence with regard to the first alternative of 33:2 (danger to the security of the country) appears to be somewhat lower as it demands only "reasonable grounds for regarding". According to Grahl-Madsen the expression, "security of the country" is equivalent to the common term "national security"; he suggests that the wording was made deliberately vague to allow states to make their own qualified judgement on this matter. Grahl-Madsen, A., Commentary Art. 33 para 6 and 8. Gilbert takes a different position, claiming that "danger to the security of the country" represent a "more demanding idea [../..] more akin to the threshold necessary to derogate from human rights obligations." Gilbert at p.26.
} 
Hence, if expulsion is possible not only on the grounds of 33(2) but also on the grounds of Article $1 \mathrm{~F}$, this is no longer a matter of legal technicalities. It effectively widens the scope of application and extends the exception to the protection against refoulement beyond what was foreseen by the CSR51 and beyond what is permitted. In my opinion, there are good reasons for believing that the German confusion of concepts may thus risk causing unlawful cases of refoulement and make Germany responsible for violations of international law.

The possible infringement of the protection against refoulement may be the most evident shortcoming of the legislator in this regard. It is also the issue that has received the most attention in various commentaries on the regulation. Unfortunately, the German implementation of the exclusion clause gives rise to yet a number of further concerns, some of which are less obvious, but no less serious.

\subsubsection{Exclusion before inclusion}

On a procedural level, Günter Renner, a German judge, has pointed out that the incorporation of the exclusion clause in Article 51 of the AuslG does not prevent the administration nor the courts, from determining refugee claims on the sole basis of the exclusion clause, without ever considering the issue of persecution. ${ }^{134}$ Reinhard Marx goes as far as saying that the location of the exclusion clause indicates that the legislator did not want an investigation on the inclusion grounds to be carried out. ${ }^{135}$ The issue is problematic. UNHCR has, on a number of occasions, stressed the need for a holistic approach to the refugee status determination and that the exclusion clause should only be used "after the adjudicator is satisfied that the individual fulfils the criteria for refugee status". ${ }^{136}$ Generally, the call for "inclusion before exclusion" is founded on good arguments. Following the "exceptional nature" of the exclusion clause it has often been concluded that Article $1 \mathrm{~F}$ cannot consistently be used as a general screening devise to shorten the determination procedure. ${ }^{137}$ Such a procedure would also impair the prospects for a fair and full examination of the circumstances in each

\footnotetext{
${ }^{134}$ Renner, G., 'Terrorismusbekämpfung und Schutzsuchende’, “[W]eder im Verwaltungsnoch im Gerichtsverfahren [kann] wirksam eine Praxis verhindert werden, die darauf hinausläuft, den Ausschluss festzustellen, ohne zuvor den Verfolgungstatbestand zu prüfen.” p. 58. See also Davy, U., 'Terrorismusbekämpfung und staatliche Schutzgewährung', Zeitung für Ausländerrecht 2 (2003), 44-52.

${ }^{135}$ Marx, R., 'Zu den ausländer- und asylrechtlichen Bestimmungen des Terrorismusbekämpfungsgestzes’, Zeitschrift für Ausländerrecht, 4 (2002) 133.

${ }^{136}$ UNCHR, Guidelines on the Application of the Exclusion Clauses, December 1996.

${ }^{137}$ Lawyers committee for Human Rights 'Safeguarding the Rights of Refugees under the Exclusion Clauses: Summary Findings of the Project and a Lawyers Committee for Human Rights Perspective', p. 325; Nyinah, M. K., p. 305.
} 
individual case. On a more practical level, the Lawyers Committee for Human Rights reports that, especially in situations of mass influx, it has proven hard to find the necessary co-operation of individuals if the investigation appears to be made with the primary intention of exclusion (rather than identifying protection needs). ${ }^{138}$

Good arguments aside, in the application of the exclusion clause, state practice varies considerably. ${ }^{139}$ As Article $1 \mathrm{~F}$ does not make explicit referrals to a particular process or order of the determination, states sometimes claim that the issue has been left to the discretion of the sovereign state. In support of the exclusion before inclusion track, references are often made to the mandatory phrasing of Article $1 \mathrm{~F}$. While states are, in the end, obliged to deny refugee status to excludable individuals, Article $1 \mathrm{~F}$ may seem a time and cost saving admissibility test. ${ }^{140}$ Recently, James Hathaway has supported this approach. ${ }^{141}$ This line of argumentation, of course, is subject to the same criticism as mentioned above. Nevertheless, UNHCR commentaries are just as non-binding as those of the Lawyers Committee for Human Rights and in view of the diverging state practice the remark by Reinhard Marx that the principle "inclusion before exclusion" would be an accepted principle of law (annerkannter Grundsatz) is not entirely convincing. ${ }^{142}$

Hence, although legal as well as practical arguments strongly advise that inclusion be determined before exclusion, I would not, at this point, like to conclude that Germany is therefore in violation of international law.

\footnotetext{
${ }^{138}$ Lawyers committee for Human Rights 'Safeguarding the Rights of Refugees under the Exclusion Clauses: Summary Findings of the Project and a Lawyers Committee for Human Rights Perspective', p. 325

${ }^{139}$ The European Legal Network on Asylum (ELENA) reports that the Netherlands are practising a firm line of "exclusion before inclusion". In The United Kingdom practice is not uniform. European Legal Network on Asylum, International course on the Application of Article 1C and Article 1F of the 1951 Convention relating to the status of Refugees, 1719 January 2003. Sibylle Kapferer has found examples of 'exclusion before inclusion' also in Belgium and France. Kapferer, S., 'Exclusion Clause in Europe: A Comparative Overview of State Practice in France, Belgium, and the United Kingdom', International Journal of Refugee Law, Vol. 12, Special Supplementary Issue (2000), 195-221.

${ }^{140}$ This position is in fact, held by a considerable number of states such as Canada, Australia and the Netherlands. How many states that apply the same principle as a matter of ad hoc, authority discretion of course, is difficult to say. See Ramirez v Canada (Minister of Employment and Immigration) [1992] 2 FC 306 (CA); Sivakumar v Canada (Minister of Employment and Immigration) [1994] 1 FC 433 (CA), Dutch State Secretary of Justice, Section 1F of the Convention on Refugees, 6302011/97/DVB, 19 November 1997, p. 48.

${ }^{141}$ Hathaway, J., \& Harvey, C., ("Because no asylum seeker described in Article 1(F) can qualify for Convention refugee status, state parties to the Refugee Convention are under no duty to consider the merits of a protection claim made by such a person.”) At 264.

142 Marx, R., p. 133.
} 
Whether the German openness to the 'exclusion before inclusion' approach will find acceptance in the EC-regulation is too early to say. The European Commission has previously advocated a comprehensive approach to the determination procedure on the basis that "facts justifying the excludability of an applicant will normally emerge in the course of the 'inclusion phase' of the refugee determination process". ${ }^{143}$ Recently, however, the proposal for the Council Qualification directive, has raised some concern that the Commission would merge the criteria of inclusion and exclusion into one examination. ${ }^{144}$

\subsubsection{Manifestly unfounded claims and accelerated procedures}

Following the declaratory nature of the refugee definition, the UNHCR has often found need to stress that the protection of non-refoulement applies from the instance a person fulfils the criteria of $1 \mathrm{~A} .{ }^{145}$ The examination of cases, which could trigger an exclusion from refugee status often require a high degree of expertise, and specialised knowledge. Generally speaking, there are therefore good reasons for being cautious with the various kinds of special or expedient procedures that are commonly discussed in relation to asylum claims. As such, special procedures are not inherently detrimental to a fair and full procedure. Indeed, in a paper addressing the security concerns in connection with refugees, UNHCR suggests the establishment of special “exclusion units” which should consist of experts in relevant legal areas as well as security experts. A similar system was established in Canada in 1999, apparently with good results. ${ }^{146}$ Most discussions on special procedures, however, seem to focus on expediency rather than expertise.

In German law, manifestly unfounded asylum-claims are subject to an accelerated procedure setting a one-week limit to leave the country and limited opportunities for appeal (AsylVfG Articles 30, 36). As claims should be "manifestly" unfounded, one could draw the conclusion that only such cases are concerned where the risk of error is minimal, and the reduced legal protection is perhaps acceptable. The accelerated procedure, however, also extends to a number of asylum-claims that may not be obviously unfounded but which should nonetheless "be rejected as manifestly unfounded” (AsylVfG Art. 30 (3)). Most of the situations regard fraudulent

\footnotetext{
${ }^{143}$ Commission working paper, para 1.4.3.2. Later in the same paper the Commission takes a somewhat different position in the related issue of "accelerated procedures".

${ }^{144}$ See Qualification Directive Article 2, in connection with Article 14. See also Amnesty internationals comments on the Commissions proposal, p.1.

${ }^{145}$ See e.g. UNCHR 'Guidelines', Section (i), para. 9; Lauterpacht, E. and Bethlehem, D., 'The scope and content of the principle of non-refoulement', Opinion delivered in the framework of the global consultation, organized by UNHCR, 20 June 2001. P. 89; GrahlMadsen, A., Commentary, Art. 33 para 2.

${ }^{146}$ See Rikhof, 'Access, Asylum and Atrocities'.
} 
claims or concern individuals who have refused to co-operate it also refers, however, to cases "where the criteria of Article 51 section 3 of the Aliens Act apply". When the exclusion clause was incorporated in German law as an addition to the existing Article 51 (3) (Art. 33(2) CSR51) it therefore automatically became subject to the accelerated procedure. ${ }^{147}$ Just as obviously unfounded asylum claims, a decision of exclusion will therefore always lead to the rejection of the asylum claim as "manifestly unfounded" and a referral to the accelerated procedure (AsylVfG Articles 30, 36).

However, as mentioned earlier, the application of the exclusion clause normally involves the examination of complex issues, the carrying out of balancing tests etc. Hence, the occurrence of obvious cases for exclusion should be rare. In any case, the severe consequences of an exclusion from refugee status would, in my opinion, make an accelerated procedure ill suited for of this kind of cases. Bliss has argued that making an examination of exclusion subject to an accelerated procedure is a denial of procedural fairness that may lead to contravention by the state of its international obligations. ${ }^{148}$

Many academics, as well as the UNHCR, ECRE and the LCHR have taken a similar position. ${ }^{149}$ Interestingly, up until September 2001 the European Commission was equally opposed to making the determination of exclusion subject to an accelerated procedure. In its first Proposal for a Council Directive on minimum standards on procedures in Member States for granting and withdrawing refugee status, the Commission explicitly exempted "any application that may be rejected on the basis of Article 1(F) [...] from being considered as manifestly unfounded." 150 Two years later, the Commission adopts the opposite position. Member states may now "reject an application for asylum as manifestly unfounded if the determining authority has established that: [...] the applicant is prima facie excluded

\footnotetext{
${ }^{147}$ It would seem hard to believe that the legislator could have overseen this outcome. Nonetheless, this result is not mentioned in the rather extensive legal motives, or in any other official documents that I have seen.

${ }^{148}$ Bliss, M., 'Serious Reasons for Considering: Minimum Standards of Procedural Fairness in the Application of the Article 1F Exclusion Clauses', International Journal of Refugee Law 12 Suppl. (2000) 131.

${ }^{149}$ See UNHCR Addressing Security Concerns at para 7; ECRE, Comments from the European Council on Refugees and Exiles on the Commission Working document on the relationship between safeguarding internal security and complying with international protection obligations and instruments, May 2002, para 1.4.3.2; LCHR Safeguarding the rights of refugees, p. 324-325; Marx p. 132-133; Davy, U., 'Terrorismusbekämpfung und staatliche Schutzgewährung’, Zeitung für Ausländerrecht 2 (2003), 52.

${ }^{150}$ Proposal for a Council Directive on minimum standards on procedures in Member States for granting and withdrawing refugee status, from 20.9.2000 (COM/2000/578 final). Explanatory not at pp. 22-23.
} 
from refugee status by virtue of [the Qualification Directive]". ${ }^{151}$ In the Explanatory note the change in approach is justified by referring to the working paper on the safeguarding of internal security. As mentioned in previous section, however, the working paper suggests the establishment of special "exclusion units" where the issue of exclusion can be thoroughly investigated by relevant experts - not (as the Directive suggests) the rejection of the case as manifestly unfounded..$^{152}$

\subsubsection{Summary}

The evident shortcomings of the German implementation of the exclusion clause are associated with systematic errors of the German legislator. When the legal motives call the adding of Article $1 \mathrm{~F}$ to Article 33(2) an "Ergänzung unter der Berücksichtigung des Rechtsgedankens des Artikels $1 F^{\prime 153}$ it is hard to see how the principles of the Refugee Convention have in fact been taken in consideration. It may be the same wording but it blatantly disregards the different object and purpose of the exclusion clause and Article 33(2). As shown in section 4.4.2.1 this confusion risks expanding the exception from the protection against refoulement beyond what is provided by Article 33(2).

While the German method of implementation is not consistent with the systematics of the Refugee Convention it is, however, not arbitrary. Since the introduction of the German constitutional right to asylum, article 16 (a) has been the "real" legal basis for asylum. The Refugee Convention has held a secondary position in German asylum law, affording only "das kleine Asyl”, with a second rate residence permit. Despite repeated calls for the adoption of a refugee definition corresponding to Article 1A, the German structure was kept intact even when Article 16 (a) GG was narrowed down. With no legal tradition of reasoning along the lines of the Refugee Convention the exclusion clause was implemented according to the German practice; which as we saw in section 4.4.2 is mixing 33(2) and $1 \mathrm{~F}$ together.

Provided that this proposition is correct and the systematic errors were not a mistake but in line with the German tradition, the confusion around the implementation of Article $1 \mathrm{~F}$ risks being repeated. In such a case, problems are likely to become more critical as the Common European Asylum System

\footnotetext{
${ }^{151}$ Proposal for a Council Directive on minimum standards on procedures in Member States for granting and withdrawing refugee status, from 03.07.2002 (COM(2002)326 final). Art. 29 (c).

${ }^{152}$ Moreover, the new wording is remarkable, as it seems to introduce a new concept in the determination procedure. If, as the wording suggests, "prima facie” represents a new (lower) evidentiary threshold, I find this development very alarming.

${ }^{153}$ Deutscher Dundestag -14. Wahlperiode, Drucksache 14/7386, p. 57.
} 
takes shape. Ever since the beginning of the EU co-operation in asylum matters it was clear that a future common standard for a refugee status would have to be based on the Refugee Convention. The first statements were non-binding ${ }^{154}$ but as the CEAS unfolds, the EU will establish a refugee definition based on the Refugee Convention that will bind all its member states, making the German approach untenable.

${ }^{154}$ See JOINT POSITION of 4 March 1996 defined by the Council on the basis of Article K.3 of the Treaty on European Union on the harmonized application of the definition of the term 'refugee' in Article 1 of the Geneva Convention of 28 July 1951 relating to the status of refugees: OJ N L 63 of 13 March 1996. 


\subsection{Universal jurisdiction in Germany}

The German Criminal Code (StGB) explicitly provides universal jurisdiction (Weltrechtsgrundsatz) for a number of crimes against protected legal values (Art. $6 \mathrm{StGB}$ ). This principle is extended by a general provision to cover any crime, which Germany is obliged to adjudicate following international conventions (Art. 6 No. 9). A further rule states that German penal law shall be applicable in cases where a foreign extradition request has been denied, an interesting provision, similar in fact to our aut dedere principle. ${ }^{155}$ Combined, these three sets of rules would appear to provide a full jurisdictional basis for Germany to try international crimes. Until recently however, the German criminal law has proven remarkably illequipped to deal adequately with cases of international crimes. ${ }^{156}$ The reason appears to be a combination of the strict German approach to the principle of nullum crimen sine lege, a legislation lagging behind the developments in international law and the peculiar reluctance of the German courts to fully accept the concept of universal jurisdiction. Traditionally German courts have required a "legitimising link" (legitimierender Anknüpfungspunkt), connecting the suspect to Germany, in order to apply the universal jurisdiction. Hence, it was not enough to establish universal jurisdiction by international law, but the prosecutor would have to show an additional link, such as long-time German residency, between the accused and Germany. The argument of course is odd, as it seems to disregard that the concept of universal jurisdiction is based on the idea that, the crimes it applies to concern all states and, therefore in contrast to ordinary crimes, do not require a territorial or national link. ${ }^{157}$ A further deficiency of the old legislative framework was the lack of adequate German equivalents to the international crimes classifications. The strict adherence to the principle of nullum crimen sine lege, made it impossible to punish e.g. war crimes, and crimes against humanity as such as these did not correspond with German classifications. The situation was perhaps particularly unsatisfactory with regard to international war crimes and around the time of the Rome Conference (where Germany played an active role promoting an independent international court, based on the principle of universal

\footnotetext{
155 StGB $§ 7$ (1) no. 2.

${ }^{156}$ See e.g. Wirth, S., International Criminal Law in Germany, Presentation to the Conference Combating International Crimes Domestically, Hosted by the Canadian Department of Justice, Ottawa 22-23 April 2002; Werle, G. Implementation of the Rome Statute in Germany - The Future International Crimes Code, Paper presented at the EAPC/PfP Workshop on Prosecuting War Crimes, Interlaken, Switzerland, 17-19 October 2001. Para 5.

${ }^{157}$ The Court position has been widely criticised in the literature, see e.g. Wirth.
} 


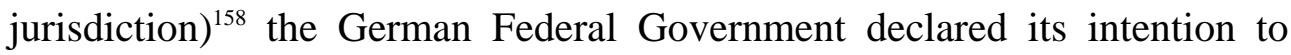
adapt the German criminal law to the Rome Statute.

The new Code of Crimes against International Law, (Völkerstrafgesetzbuch, VStGB) entered into force on 1 July 2002 and is a radical improvement. In addition to genocide, crimes against humanity and war crimes are introduced as independent crimes, each with a systematic description. ${ }^{159}$ With the new regulation the legislator also does away with the demand of a legitimising link; according to section 1, the principle of universal jurisdiction, shall apply to all crimes under international law. ${ }^{160}$ Among crimes previously not punishable in the international context are torture and 'disappearances'. The Crime Code, however, was not only intended to adjust the German Criminal law to the Rome Statute but also to bring it up to date with current obligations of international customary law. ${ }^{161}$ Consequently in its definition of 'war crimes' it expands the scope to also cover acts in "an armed conflict not of an international character" ${ }^{162}$ The Code also covers acts criminal under customary law not mentioned in the Rome Statute, such as the use of biological and chemical weapons. ${ }^{163}$

\subsubsection{The necessary legal framework to satisfy international obligations?}

It seems clear that when it comes to war crimes, relevant under the exclusion clause $1 \mathrm{~F}$ (a), the new Code provides Germany with an adequate legal framework to prosecute suspected individuals. With regard to crimes under Article $1 \mathrm{~F} \mathrm{(b)} \mathrm{and} \mathrm{(c),} \mathrm{the} \mathrm{picture} \mathrm{is} \mathrm{less} \mathrm{clear.} \mathrm{As} \mathrm{we} \mathrm{saw} \mathrm{in} \mathrm{section}$ 2.1.2, the first category includes a broad range of grave, non-political ordinary crimes, as well as particularly brutal crimes of a political nature. ${ }^{164}$ The exact scope of application of Article $1 \mathrm{~F}$ (c) is debated but has been said to include, inter alia, "terrorism". My examination in section 2.2.2 showed,

\footnotetext{
${ }^{158} \mathrm{Cf}$. the German paper circulated before the Rome Conference, promoting an independent ICC based on the principle of universal jurisdiction; The Jurisdiction Of The International Criminal Court: An Informal Discussion Paper Submitted By Germany, UN Doc.A/AC.249/1998/ DP.2, 23 March 1998.

159 See Article 6-12, Völkerstrafgesetzbuch, BGBl I 2002, 2254.

160 "This Act shall apply to all criminal offences against international law designated under this act, to serious criminal offences designated therein even if the act was committed abroad and bears no relation to Germany.” Art. 1 (1) Code of Crimes against international law. An English translation can be found at < http://www.iuscrim.mpg.de/forsch/legaltext/ vstgbleng.pdf $>$.

${ }^{161}$ BMJ Press Release Nr. 37 / 02 Berlin, am 27. Juni 2002, Das Deutsche Völkerstrafgesetzbuch tritt zum 30. Juni 2002 in Kraft.

${ }_{162}$ Chapter 2 Section 8:1.

${ }^{163}$ Section 12 (a) no. 2. It should be reminded that this is in line with the Rome Statute which explicitly does not prejudice any other application of international law (Art. 10 ICC). ${ }^{164}$ As a result of the balancing act; see section 2.2.2.2 of this essay or UNCHR Handbook § 152.
} 
however, that the principle of aut dedere aut judicare, or in this case a duty to prosecute, does not extend to all crimes under Article 1F. States have an obligation under conventional as well as customary international law to prosecute suspects of war crimes, the crimes of apartheid and torture as well as suspects of a number of crimes of international concern such as hostagetaking and hijacking. With regard to common crimes I could not find support for such an obligation. Turning again to German criminal law, the Criminal Code routinely provides jurisdiction for "[a]cts committed abroad which are made punishable by the terms of an international treaty binding on the Federal Republic of Germany". It seems then that as far as jurisdiction goes Germany would be able to prosecute at least in theory all crimes that are prohibited under conventions to which Germany is a party. In order to actually initiate an investigation Germany must, however, also have enacted the necessary national equivalents to the crimes. As mentioned in the preceding section, the strict adherence to the principle nullum poena sine lege has made it difficult in the past to enforce penalties due to the incomplete German implementation of the international classifications of crimes. The new Code of Crimes has amended this problem with regard only to war crimes. Whether the remaining area of law covered by the obligation to prosecute has been satisfactorily implemented in German law is not possible to determine in this context. As pointed out in section 2.2.2 there is a large number of conventions and bilateral agreements establishing an obligation of aut dedere aut judicare. As many of these relate to traditional "terrorist"-acts (such as taking of civilian hostages, theft of nuclear materials and hijacking), the German decision in 2001 to extend its prohibition of support and foundation of terrorist groups to such acts outside of German territory, should be of interest. The new regulation (Article 129a StBG) covers many of those crimes dealt with by international conventions and has been utilised at several occasions since its adoption in 2001, inter alia in the prosecution of persons suspected of involvement in the attacks of the 11 September. ${ }^{165}$

\subsubsection{Exercise of jurisdiction}

Whether or not the international obligation to prosecute certain crimes is effective will, in the end, depend on the extent to which the national prosecutor is willing to make use of the jurisdiction. In principle the German prosecutor has an obligation to open investigations if there are sufficient

\footnotetext{
${ }^{165}$ See Generalbundesanwalt beim Bundesgerichtshof (GBA), Federal Prosecutor General lays further indictment for involvement in 9/11. 17/2003 of 09.05.2003.
} 
factual grounds. ${ }^{166}$ When it comes to crimes punishable under the Code of Crimes under international law this duty is complemented by certain exceptions. ${ }^{167}$ One is that the prosecutor may refrain from prosecuting acts committed abroad if the suspect is neither present nor expected to arrive on German territory. ${ }^{168}$ Excludable individuals will of course inevitably be on German territory. The optional right to refrain from prosecution however also applies in cases where a crime has been committed abroad and neither the suspect, nor the victim, are German nationals. How far this exception goes with regard to excluded individuals is not regulated by law.

Whereas the new Code of Crimes provides good opportunities to prosecute persons suspected of international crimes, the StPO also seems to provide the prosecution with quite an extensive margin of discretion with regard to opening investigations. It is possible that the high profile taken by the German Government at the Rome Conference may motivate the state prosecutor to take a more active role, at least when it comes to war crimes and crimes against humanity.

\subsection{Consequences of exclusion}

\subsubsection{Institutionalised toleration}

In the motives to the Terrorismusbekämpfungsgesetz the legislator recognises that, following international conventions, it may not be possible to expel all persons excluded by the new regulation. It does not mention, however, how to proceed with this group of excludable non-removable individuals. Studying the motives, as well as academic commentaries this issue appears to be widely ignored. Indeed, contacts with the Federal Ministry of the Interior (BMI) confirm that there is in fact no special plan or guideline governing the treatment of excluded individuals. According to the BMI an excluded, yet non-removable person, will most likely receive a socalled Duldung (roughly: “toleration”). This is no residence permit as such, but rather an institutionalised acceptance of the alien's presence in the territory, which, in contradiction to a stay without the Duldung is not punishable. It does not, however, improve the legal status of the rejected; he or she will still be under an obligation to leave the territory, although this obligation has been stayed. The Duldung is always temporary and should

\footnotetext{
166 “[Die Staatsanwaltschaft] ist, soweit nicht gesetzlich ein anderes bestimmt ist, verpflichtet, wegen aller verfolgbaren Straftaten einzuschreiten, sofern zureichende tatsächliche Anhaltspunkte vorliegen.” (StPO § 152 (2).)

${ }^{167}$ StPO § $153 f$.

${ }^{168}$ Wirth, S., p. 9.
} 
not be set longer than a year. Often, however, the status is renewed after the expiry of the period, sometimes over several years ("Ketten-Duldung"). The Duldung is only valid in the issuing region; for practical and administrative reasons this limit is often set to the Bundesland; any defection from this area is considered a criminal act.

Establishing the individual residential status is more than merely a formality. In Germany residential status is particularly important as it will determine a number of social and legal rights and benefits such as the right to vote or to hold office, right to social benefits, access to higher education etc.

It is possible, after a certain time and under certain conditions, to transform a Duldung into a residence permit with corresponding rights and benefits. As we shall see in subsequent sections, however, the requirements are such that this will not normally happen and therefore leave the individual with the same legal status that she was originally awarded.

\subsubsection{Social rights and benefits}

Since the introduction of the welfare state by Chancellor Bismarck in the 1890s, Germany has been keen to maintain a high social standard. Indeed, the 1949 German constitution even places the social aspects along with democracy as the founding values of the German state. ${ }^{169}$ Although general principles on social rights and benefits are regulated federally the responsibility of ensuring its implementation and the issuing of detailed regulations rests with the Länder. ${ }^{170}$ With regard to the federal level, the governing provisions are found in the Bundessozialhilfegesetz. This set of rules, however, does not apply to individuals with a Duldung who are explicitly excluded from the general social benefit scheme. Excluded people will therefore receive allowances at a lower level, and equivalent to what is given asylum seekers during the asylum-claim investigation phase (Asylbewerberleistungsgesetz). Today, the fixed amount for a single adult is $40,90 €$ a month. The necessary need of nutrition, housing, clothing, heating, and medical service should, as a principle, be provided in kind. ${ }^{171}$ How this principle is implemented in practice differs between the Länder. Generally, housing will be provided but public accommodation is often crowded and criticised by independent social workers for its poor standard. While

\footnotetext{
${ }^{169}$ Art. 20 GG (1). .Die Bundesrepublik Deutschland ist ein demokratischer und sozialer Bundesstaat.“

${ }^{170}$ To have an overall picture I have consulted Georg Classen, Flüchtlingrat Berlin, and Julia Duchrow, Amnesty international German Section.

${ }^{171}$ Art. 3 AsylbLG. The amount was recalculated with the introduction of the Euro in January 2001. The absolute amount however has been unchanged since 1993.
} 
individuals have no legal right to choose their own private accommodation such applications are commonly granted. In such cases, individuals will receive some contribution to meet the rent and the cost of heating and household goods. In addition, people living outside the public accommodation will receive the equivalent of $224,97 €$ a month to cover other costs, such as food, clothing and personal hygiene. Still, the principle of allowances in kind is upheld by many states, which chose to provide the amount in vouchers, or, as in some Länder, even in food-parcels.

It should also be noted that the Duldung does not entail a right to the usual financial child benefits.

\subsubsection{Working permit, education}

Under German alien's law the Länder can prohibit individuals with a Duldung from attaining both higher education (vocational training and university studies) and taking on paid jobs. It may be interesting to note that eight of the German Länder also exempt children with this status from the compulsory school attendance. This differential treatment with regard to education could be difficult to reconcile with the International Convention on the Right of the Child, had Germany not issued a reservation to the convention. ${ }^{172}$

Usually states tend to prohibit higher education but to allow people with this status to work. ${ }^{173}$ Even when permitted to work however, third state nationals have only a secondary access to the labour market (nachrangiger Arbeitsmarktzugang) which allows them to work only if no one else (that is a German or a person with a permanent residence permit) can fill the particular position. Obviously the practical implication of this principle will vary depending on the employment opportunities in the state. With today's unemployment rates, however, the chances that a person on Duldung obtains a legal paid job, seem minimal.

\subsubsection{Conclusion}

It should be clear that the status Germany offers to excluded individuals is not one of priority. They receive social benefits at a level much lower than the level prescribed in the Bundessozialhilfegesetz, and, as a principle in

\footnotetext{
172 "[No] provision [may] be interpreted to mean that it restricts the right of the Federal Republic of Germany to pass laws and regulations concerning the entry of aliens and the conditions of their stay or to make a distinction between nationals and aliens."

${ }^{173}$ Some states have chosen a midway. In Berlin "tolerated" individuals are in fact permitted to study. Taking up university studies however, they automatically lose their right to social benefits and not being in possession of a permanent residence-permit, they are not entitled to the general students financing-scheme.
} 
kind. They have little or no opportunity to attend higher education or vocational training and their children may be exempted from compulsory school attendance. Their chances of finding legal employment are significantly impaired by a combination of a high general unemployment and a secondary access to the labour market. Perhaps more importantly, their chances of improving their situation are slim, providing limited incentives for integration.

This report, however, leaves at least one key question unanswered. I have established that the group with a Duldung obviously live an insecure life, their stay in Germany is tenuous and their situation bleak. They often do not know if they will be allowed to stay another year or another six months depending on the length of their permit. As far as social rights and benefits go they are not only disadvantaged they are also on the bottom of the social ladder, forced, for example, to shop using food-stamps. It is not farfetched to wonder what effects such social experiences may have on a person.

From the perspective of the German government another question seems to be even more pressing: how will persons with a criminal past be affected? Considering the background of the perpetrators of the terrorist acts of September 11th, it is clear that the psychology of terrorism is a very complex topic. However, it certainly does not seem to be a forward-looking, risk-minimising strategy to treat the sensitive group of excluded but nonremovable persons in the way it is done in Germany. 


\section{Concluding remarks}

Terrorism is not a new phenomenon but has since 11 September reached a new dimension. So has the interest for the exclusion clause of the Refugee Convention. While most research on the exclusion clause has revolved around the application of the provision, the subject of this thesis has been to examine the post-exclusion phase. The focus has been on a very particular segment of this group; individuals who, due to their alleged involvement in serious crimes have been excluded from refugee status but who for various reasons can neither be expelled nor extradited. I have examined not only state obligations with regard to this group but have also directed a closer look at actual state practice. Some of the findings have been interesting and call for further attention.

\subsection{A partial legal obligation to prosecute}

Among refugee scholars there has been a tendency to discharge the question of excluded non-removable persons with a general reference to the principle of aut dedere aut judicare. If someone who is excluded from refugee status is not removed or extradited, the host state should make sure to prosecute that individual under its own jurisdiction. It seems to be a perfect solution, yet no one has ever made sure to investigate just how far the principle is in fact applicable in relation to $1 \mathrm{~F}$ crimes. Within the discipline of international criminal law, the debate on a possible international obligation to prosecute certain crimes is animated and has been ongoing for years. There has been increasing support for the argument that the principle of aut dedere aut judicare may, to a greater or lesser extent, be developing into a principle of customary international law. Enache-Brown and Fried go as far as claiming that the common conventional obligation to prosecute certain crimes has "generalised" into an obligation of customary international law, covering not only the area of the relevant conventions but all international crimes and irrespective of treaty ratification. Bassiouni and Goodwin-Gill propose a similar argument, claiming that the principle of aut dedere aut judicare would represent an obligation erga omnes, binding on all states. As we have seen earlier in this essay some of these claims are in fact founded on good arguments. The problem, however, is that despite a large number of conventions prescribing that perpetrators of certain crimes are to be prosecuted such an obligation erga omnes is not supported by evidence of state practice. States do not always prosecute crimes even against 
established values of jus cogens. ${ }^{174}$ Hence, although moral as well as legal arguments seem to indicate that there should be an international obligation to prosecute the most serious crimes, state practice today does not give enough evidence to establish such a principle.

This is not to say that there is no obligation on the part of states to prosecute crimes relevant to Article 1F. With regard to many of the acts and crimes mentioned in the article the duty to extradite or prosecute applies as a matter of conventional law.

In most jurisdictions, however, even a well-established international obligation to prosecute a certain crime does not in itself authorise the prosecution to open an investigation. For a long time German prosecutors could not, for example, prosecute certain war crimes due to inadequate national implementation of the international crime classifications. The entry into force of the new Code of Crimes Against International Law seems to have amended this shortcoming at least as far as war crimes and crimes against humanity go. Whether the new Code of Crimes will in practice prove sufficient to fulfil the German international obligation to prosecute certain international crimes is hard to say at this stage. That will, in the end, depend on the independent decisions of the prosecutors, as well as the rulings of the courts. It is obvious, however, that if the Code shall indeed serve to "maintain the German role as the motor of the development of the international criminal law" ${ }^{175}$ its prosecutors should make sure not to take their task too lightly. With regard to crimes under universal jurisdiction the German state prosecutors have a rather wide margin of discretion on whether or not to open investigations in a particular case. It has not been possible in this context to determine to what extent that state prosecutors actually make use of their jurisdiction with regard to $1 \mathrm{~F}$ crimes. In general we can assume that crimes leading to exclusion will typically have taken place outside the country of refuge and thereby regularly be complicated and, above all costly, to investigate.

\subsection{Implementing quandaries}

In Germany the project of implementing the exclusion clause proved to be problematic on several levels. In the motives to the amending regulation, the legislator asserts that it will implement the exclusion clause "unter

\footnotetext{
${ }^{174}$ Bassiouni, International crimes, p. 66.

175 Zimmermann, A., 'Bestrafung Völkerrechtlicher Verbrechen duch deutsche Gerichte nach In-Kraft-Treten des Völkerstrafgesetzbuchs', Neue Juristische Wochenschrift 42 (2002) 3068-3070. p. 3070.
} 
Berücksichtigung des Rechtsgedankens des Artikels 1F”. In view of the result it is hard to see what exactly has been taken into consideration. Rather than following the structure of the Refugee Convention, it follows the structure of its own legal tradition. By adding the exclusion criteria to its existing equivalent to article 33(2) of the Refugee Convention, the German exception from protection against refoulement is potentially expanded. The implementation is hardly consistent with the Refugee Convention. Worse still, at least from the position of the German government, it is hardly reconcilable with the emerging EU framework. This may prove a far more acute problem for Germany.

While the EU system has, at least in theory, endorsed a "full and inclusive" implementation of the Refugee Convention, Germany has been reluctant to implement even the most basic provisions, the inclusion and the exclusion clause. What this, in the end, will mean to the German Alien Act is not quite clear. In the negotiations on the Qualification Directive, Germany has objected to almost every substantial provision challenging its traditional structure. ${ }^{176}$ When the Directive seems to come about nonetheless, Germany will need to review its Alien Act.

Perhaps the change will not be so hard after all. Over the last rounds of negotiations in the Council for Justice and Home Affairs, member states seemed to falter in their determination to adopt just such a 'full and inclusive' interpretation of the Refugee Convention as originally maintained. Their sudden shift on the issue of manifestly unfounded claims, the peculiar introduction of a new threshold to exclusion - certainly not a feature of the Refugee Convention - and their ambiguous position on the issue of "inclusion before exclusion" seems to indicate just that.

The German implementation of the exclusion clause turned out to be problematic also on a practical level. While states are under no legal obligation to provide excluded, non-removable individuals with any social benefits it is doubtful whether the German approach will have the anticipated effect of keeping in check milieus, which may foster the growth of religious or political radicalism. Indeed the current legal arrangement with regard to this group of people does not seem very appropriate. It not only sanctions impunity; it is also functionally inadequate, as it does not effectively deal with this group of people. Considering the remarkably poor conditions that the group of excluded persons live under, it may be tempting to conclude that that is a way of punishment. My impression, in the German

\footnotetext{
${ }^{176}$ Pro Asyl, Presseerklärung, Rat Justiz und Inneres in Brüssel. Gemeinsames EUAsylrecht droht an Deutschland zu scheitern, 8. April 2003.
} 
case however, is that this group of people have simply been overlooked by the administration in their rush to implement the exclusion clause and strike back at terrorism.

The German situation also gives rise to concerns regarding the recent development in the European Union. The Qualification Directive, awaiting adoption by the Council has, in a way, extended the German approach to the whole of the European Union. The Directive's exclusion of 1F cases both from protection as a refugee and from subsidiary protection is in accord with the Refugee Convention, and general human rights law. It suffers, however, from the same problem as the German legislation as it does not solve the issue of the fate of the excluded persons.

When it comes to the issue of excluded non-removable persons there are no easy solutions. If states are serious in their intent to prevent impunity, fight terrorism and act in conformity with the object and purpose of the Refugee Convention, it seems to me that the most expedient solution would be to implement consistent and comprehensive rules to exercise their universal jurisdiction in all cases where it applies. As shown earlier in this essay, states should be able to maintain an argument of permissive universal jurisdiction with regard to almost all crimes leading to exclusion. By recognising their obligation states would effectuate the object and purpose of the exclusion clause, and establish the missing state practice. 


\section{Supplement A: excerpts from international law}

Convention relating to the Status of Refugees (28 July 1951, 189 UNTS 137).

Article 1. Definition of the term "Refugee"

F. The provisions of this Convention shall not apply to any person with respect to whom there are serious reasons for considering that:

(a) he has committed a crime against peace, a war crime, or a crime against humanity, as defined in the international instruments drawn up to make provision in respect of such crimes;

(b) he has committed a serious non-political crime outside the country of refuge prior to his admission to that country as a refugee;

(c) he has been guilty of acts contrary to the purposes and principles of the United Nations.

\section{Article 33. Prohibition of expulsion or return ("refoulement")}

1. No Contracting State shall expel or return ("refouler") a refugee in any manner whatsoever to the frontiers of territories where his life or freedom would be threatened on account of his race, religion, nationality, membership of a particular social group or political opinion.

2. The benefit of the present provision may not, however, be claimed by a refugee whom there are reasonable grounds for regarding as a danger to the security of the country in which he is, or who, having been convicted by a final judgement of a particularly serious crime, constitutes a danger to the community of that country. 


\section{Supplement B: excerpts from European Community law}

Proposal for a COUNCIL DIRECTIVE on minimum standards for the qualification and status of third country nationals and stateless persons as refugees or as persons who otherwise need international protection, Brussels, 12.9.2001 COM(2001) 510 final.

\section{Article 14. Exclusion from refugee status}

1. Member States shall exclude from refugee status any applicant:

(a) who is at present receiving protection or assistance from organs or agencies of the United Nations other than the United Nations High Commissioner for Refugees;

(b) who is recognised by the competent authorities of the country in which he or she has taken up residence as having the rights and obligations attached to the possession of the nationality of that country;

(c) wherethere are serious reasons for considering that:

(i) the applicant has committed a crime against peace, a war crime, or a crime against humanity, as defined in the international instruments drawn up to make provision in respect of such crimes;

(ii) the applicant has committed a serious non-political crime prior to his or her admission as a refugee;

(iii) the applicant has been guilty of acts contrary to the purposes and principles of the United Nations.

2. The grounds for exclusion shall be based solely on the personal and knowing conduct of the person concerned.

3. Member States shall ensure that persons so excluded have the right to bring proceedings before a court against a decision to exclude them from international protection.

4. The application of the exclusion shall not in any manner affect obligations that Member States have under international law.

\section{Article 17. Exclusion from subsidiary protection status}

1. Member States shall exclude from subsidiary protection status any applicant where there are serious reasons for considering that:

(a) the applicant has committed a crime against peace, a war crime, or a crime against humanity, as defined in the international instruments drawn up to make provision in respect of such crimes;

(b) the applicant has committed a serious non-political crime prior to his or her admission as a refugee;

(c) the applicant has been guilty of acts contrary to the purposes and principles of the United Nations.

2. The grounds for exclusion shall be based solely on the personal and knowing conduct of the person concerned.

3. Member States shall ensure that persons so excluded have the right to bring proceedings before a court against a decision to exclude them from international protection.

4. The application of the exclusion shall not in any manner affect obligations that Member States have under international law. 


\section{Supplement C: excerpts from}

Gesetz über die Einreise und den Aufenthalt von Ausländern im Bundesgebiet (Ausländergesetz - AuslG). Vom 9. Juli 1990 (BGBl. I S. 1354) zuletzt geändert durch Gesetz vom 09.01.2002 (BGBl. I S. 361 - Terrorismusbekämpfungsgesetz).

\section{§ 51 Verbot der Abschiebung politisch Verfolgter}

(1) Ein Ausländer darf nicht in einen Staat abgeschoben werden, in dem sein Leben oder seine Freiheit wegen seiner Rasse, Religion, Staatsangehörigkeit, seiner Zugehörigkeit zu einer bestimmten sozialen Gruppe oder wegen seiner politischen Überzeugung bedroht ist.

(2) Die Voraussetzungen des Absatzes 1 liegen vor bei

1. Asylberechtigten und

2. sonstigen Ausländern, die im Bundesgebiet die Rechtsstellung ausländischer Flüchtlinge im Sinne des Abkommens über die Rechtsstellung der Flüchtlinge anerkannt sind.

In den sonstigen Fällen, in denen sich der Ausländer auf politische Verfolgung beruft, stellt das Bundesamt für die Anerkennung ausländischer Flüchtlinge in einem Asylverfahren nach den Vorschriften des Asylverfahrensgesetzes fest, ob die Voraussetzungen des Absatzes 1 vorliegen. Die Entscheidung des Bundesamtes kann nur nach den Vorschriften des Asylverfahrensgesetzes angefochten werden.

(3) Absatz 1 findet keine Anwendung, wenn der Ausländer aus schwerwiegenden Gründen als eine Gefahr für die Sicherheit der Bundesrepublik Deutschland anzusehen ist oder eine Gefahr für die Allgemeinheit bedeutet, weil er wegen eines Verbrechens oder besonders schweren Vergehens rechtskräftig zu einer Freiheitsstrafe von mindestens drei Jahren verurteilt worden ist.

Das Gleiche gilt, wenn aus schwerwiegenden Gründen die Annahme gerechtfertigt ist, dass der Ausländer ein Verbrechen gegen den Frieden, ein Kriegsverbrechen oder ein Verbrechen gegen die Menschlichkeit im Sinne der internationalen Vertragswerke, die ausgearbeitet worden sind, um Bestimmungen bezüglich dieser Verbrechen zu treffen, begangen hat oder dass er vor seiner Aufnahme als Flüchtling ein schweres nichtpolitisches Verbrechen außerhalb des Gebietes der Bundesrepublik Deutschland begangen hat oder sich hat Handlungen zuschulden kommen lassen, die den Zielen und Grundsätzen der Vereinten Nationen zuwiderlaufen.

(4) Soll ein Ausländer abgeschoben werden, bei dem die Voraussetzungen des Absatzes 1 vorliegen, kann nicht davon abgesehen werden, die Abschiebung anzudrohen und eine angemessene Ausreisefrist zu setzen. In der Androhung sind die Staaten zu bezeichnen, in die der Ausländer abgeschoben werden darf.

(5) Liegen die Voraussetzungen des Absatzes 1 vor, kann nicht davon abgesehen werden, die Abschiebung anzudrohen, eine angemessene Frist zu setzen und in der Androhung die Staaten zu bezeichnen, in die der Ausländer nicht abgeschoben werden darf.

\section{§ 52 Abschiebung bei möglicher politischer Verfolgung}

In den Fällen des $\S 51$ Abs. 3 kann einem Ausländer, der einen Asylantrag gestellt hat, abweichend von den Vorschriften des Asylverfahrensgesetzes die Abschiebung angedroht und diese durchgeführt werden. 


\section{§ 53 Abschiebungshindernisse}

(1) Ein Ausländer darf nicht in einen Staat abgeschoben werden, in dem für diesen Ausländer die konkrete Gefahr besteht, der Folter unterworfen zu werden.

(2) Ein Ausländer darf nicht in einen Staat abgeschoben werden, wenn dieser Staat den Ausländer wegen einer Straftat sucht und die Gefahr der Todesstrafe besteht. In diesen Fällen finden die Vorschriften über die Auslieferung entsprechende Anwendung.

(3) Liegt ein förmliches Auslieferungsersuchen oder ein mit der Ankündigung eines Auslieferungsersuchens verbundenes Festnahmeersuchen eines anderen Staates vor, kann der Ausländer bis zur Entscheidung über die Auslieferung nicht in diesen Staat abgeschoben werden.

(4) Ein Ausländer darf nicht abgeschoben werden, soweit sich aus der Anwendung der Konvention zum Schutze der Menschenrechte und Grundfreiheiten vom 04. November 1950 (BGBl. 1952 II S. 686) ergibt, dass die Abschiebung unzulässig ist.

(5) Die allgemeine Gefahr, dass einem Ausländer in einem anderen Staat Strafverfolgung und Bestrafung drohen können, und, soweit sich aus den Absätzen 1 bis 4 nicht etwas anderes ergibt, die konkrete Gefahr einer nach der Rechtsordnung eines anderen Staates gesetzmäßigen Bestrafung stehen der Abschiebung nicht entgegen.

(6) Von der Abschiebung eines Ausländers in einen anderen Staat kann abgesehen werden, wenn dort für diesen Ausländer eine erhebliche konkrete Gefahr für Leib, Leben oder Freiheit besteht. Gefahren in diesem Staat, denen die Bevölkerung oder die Bevölkerungsgruppe, der der Ausländer angehört, allgemein ausgesetzt ist, werden bei Entscheidungen nach $\S 54$ berücksichtigt.

Strafprozessordnung. Vom 7. 4. 1987 (BGBl. I S. 1074; 1319) zuletzt geändert durch Gesetz vom 15.02.2002 (BGBl. I S. 682).

\section{$\S 153 \mathrm{f}$}

(1) Die Staatsanwaltschaft kann von der Verfolgung einer Tat, die nach den $\S \S 6$ bis 14 des Völkerstrafgesetzbuches strafbar ist, in den Fällen des § 153c Abs. 1 Nr. 1 und 2 absehen, wenn sich der Beschuldigte nicht im Inland aufhält und ein solcher Aufenthalt auch nicht zu erwarten ist. Ist in den Fällen des § 153c Abs. 1 Nr. 1 der Beschuldigte Deutscher, so gilt dies jedoch nur dann, wenn die Tat vor einem internationalen Gerichtshof oder durch einen Staat, auf dessen Gebiet die Tat begangen oder dessen Angehöriger durch die Tat verletzt wurde, verfolgt wird.

(2) Die Staatsanwaltschaft kann insbesondere von der Verfolgung einer Tat, die nach den $\S \S 6$ bis 14 des Völkerstrafgesetzbuches strafbar ist, in den Fällen des $\S 153 c$ Abs. 1 Nr. 1 und 2 absehen, wenn

1. kein Tatverdacht gegen einen Deutschen besteht,

2. die Tat nicht gegen einen Deutschen begangen wurde,

3. kein Tatverdächtiger sich im Inland aufhält und ein solcher Aufenthalt auch nicht zu erwarten ist und

4. die Tat vor einem internationalen Gerichtshof oder durch einen Staat, auf dessen Gebiet die Tat begangen wurde, dessen Angehöriger der Tat verdächtig ist oder dessen Angehöriger durch die Tat verletzt wurde, verfolgt wird.

Dasselbe gilt, wenn sich ein wegen einer im Ausland begangenen Tat beschuldigter Ausländer im Inland aufhält, aber die Voraussetzungen nach Satz 1 Nr. 2 und 4 erfüllt sind und die Überstellung an einen internationalen Gerichtshof oder die Auslieferung an den verfolgenden Staat zulässig und beabsichtigt ist.

(3) Ist in den Fällen des Absatzes 1 oder 2 die öffentliche Klage bereits erhoben, so kann die Staatsanwaltschaft die Klage in jeder Lage des Verfahrens zurücknehmen und das Verfahren einstellen. 


\section{$\S 152$ (StPO)}

(1) Zur Erhebung der öffentlichen Klage ist die Staatsanwaltschaft berufen.

(2) (2) Sie ist, soweit nicht gesetzlich ein anderes bestimmt ist, verpflichtet, wegen aller verfolgbaren Straftaten einzuschreiten, sofern zureichende tatsächliche Anhaltspunkte vorliegen.

Strafgesetzbuch (STGB).Vom 13.11.1998 (BGBl. I S. 3322), zuletzt geändert durch Gesetz vom 22.8.2002 (BGBl. I S. 3390) m.W.v. 30.8.2002.

\section{§ 129a (StGB) Bildung terroristischer Vereinigungen}

Wer eine Vereinigung gründet, deren Zwecke oder deren Tätigkeit darauf gerichtet sind,

(1) Mord (§ 211) oder Totschlag (§ 212) oder Völkermord (§ 6 des Völkerstrafgesetzbuches) oder Verbrechen gegen die Menschlichkeit (§ 7 des Völkerstrafgesetzbuches) oder Kriegsverbrechen (§§ 8, 9, 10, 11 oder 12 des Völkerstrafgesetzbuches),

(2) Straftaten gegen die persönliche Freiheit in den Fällen des § 239a oder des § 239b oder

(3) Straftaten nach § 305a oder gemeingefährliche Straftaten in den Fällen der §§ 306 bis 306c oder 307 Abs. 1 bis 3, des $\S 308$ Abs. 1 bis 4, des $\S 309$ Abs. 1 bis 5, der $\S \S 313,314$ oder 315 Abs. 1, 3 oder 4, des $\S 316$ b Abs. 1 oder 3 oder des $\S 316 c$ Abs. 1 bis 3

zu begehen, oder wer sich an einer solchen Vereinigung als Mitglied beteiligt, wird mit Freiheitsstrafe von einem Jahr bis zu zehn Jahren bestraft. 


\section{Bibliography}

Amnesty international, Comments on the Commission's Proposal for a Council Directive on Minimum Standards for the Qualification and Status of Third Country National and Stateless Persons as Refugees or as Persons Who Are Otherwise in Need of International Protection, COM (2001) 510 final. 2 October 2002.

Amnesty international, Universal Jurisdiction. The Duty of States to Enact and Enforce Legislation. (AI index: IOR 53/005/2001).

Amnesty international, Stellungnahme von Amnesty international zum Entwurf eines Gesetzes zur Bekämpfung des internationalen Terrorismus (Terrorismusbekämpungsgesetz), of 28 November 2001.

Battjes, H., 'A balance between fairness and Efficiency? The Directive on International Protection and the Dublin Regulation', European Journal of Migration Law, 4 (2002), 159-192.

Bliss, M., 'Serious Reasons for Considering: Minimum Standards of Procedural Fairness in the Application of the Article 1F Exclusion Clauses', International Journal of Refugee Law, 12 Suppl. (2000) 92 - 132.

Bassiouni, C., 'International Crimes: Jus Cogens and Obligatio Erga Omnes’, Law and Contemporary Problems, 59/4 (1996), 63-74.

Bassiouni, C. \& Wise, E., Aut Dedere Aut Judicare: The Duty to Extradite or Prosecute in International Law (Dordrecht: Nijhoff, 1995).

BMJ Press Release Nr. 37 / 02 Berlin, am 27. Juni 2002, Das Deutsche Völkerstrafgesetzbuch tritt zum 30. Juni 2002 in Kraft.

Broomhall, B., 'Towards the Development of an Effective System of Universal Jurisdiction for Crimes under International Law', New England Law Review, 35/2 (2001), 399-420.

Davy, U., 'Terrorismusbekämpfung und staatliche Schutzgewährung', Zeitung für Ausländerrecht 2 (2003), 44-52.

Dent, J. A., Research paper on the social and economic rights of nonnationals in Europe, Commissioned by the European Council on Refugees and Exiles (ECRE).

Dugard, J. \& Van den Wyngaert, C., 'Reconciling Extradition with Human Rights', American Journal of International Law, 92/1(1998), 187-212. 
European Legal Network On Asylum, International course on the application of Article $1 \mathrm{C}$ and Article $1 \mathrm{~F}$ of the 1951 Convention relating to the status of Refugees, 17-19 January 2003.

ECRE, Comments from the European Council on Refugees and Exiles on the Commission Working document on the relationship between safeguarding internal security and complying with international protection obligations and instruments, May 2002.

Enache-Brown, C. \& Fried, A., 'The Obligation of Aut Dedere Aut Judicare in International Law’, McGill Law Journal, 42 (1998), 613-633.

Fitzpatrick, J., The Human Rights of Migrants, Conference on International Legal Norms and Migration Geneva, 23-25 May 2002.

Fritz. R., (ed.) Gemeinschaftskommentar zum Ausländerrecht, (Neuwied: Luchterhand, 1995).

Frowein, J. A., 'Jus Cogens’ in R. Bernhardt (ed.) Encyclopedia of Public International Law 2 (Amsterdam: North-Holland, 1997).

Frowein, J. A. \& Zimmermann, A., Der völkerrechtliche Rahmen für die Reform des deutschen Asylrechts (Köln: Bundesanzeiger, 1993).

Generalbundesanwalt beim Bundesgerichtshof (GBA), Federal Prosecutor General lays further indictment for involvement in 9/11. 17/2003 of 09.05.2003.

Gilbert, G., Current Issues in the Application of the Exclusion Clauses', in UNHCR, Global Consultations on International Protection in the context of the $50^{\text {th }}$ anniversary of the 1951 Convention relating to the Status of Refugees.

Goodwin-Gill, G., The Refugee in International law (Oxford: Claredon, 1996).

Goodwin-Gill, G. S., 'Crime in international law: Obligations erga omnes and the Duty to Prosecute', in Goodwin-Gill, G. S and Talmon, S. (eds.) The reality of International law, Essays in Honour of Ian Brownlie, (Oxford: Clarendon Press, 1999) 199-224.

Gorlick, B., 'The Convention against Torture: a complementary protection regime for refugees', International Journal of Refugee Law 11/3 (1999), 479-495.

Göbel-Zimmerman, R., Asyl- und Flüchtlingsrecht NJW-Schriften 41/2, (München: C.H. Beck, 1999). 
Grahl-Madsen, A., Commentary on the Refugee Convention 1951, Vol. 3, articles 31-37 (Geneva,1963).

Grahl-Madsen, A., The Status of Refugees in International Law, Vol. 1 (Leyden: Sijthoff, 1966).

Joppke, C., 'Asylum and State Sovereignty: A Comparison between the United States, Germany, and Britain', in Joppke, C. (ed.) Challenge to the Nation State, (Oxford : Oxford University Press, 1998).

Joyner, C. C., 'Arresting Impunity: The Case for Universal Jurisdiction in Bringing War Criminals to Accountability', Law and Contemporary Problems, 59/4 (1996), 153-172.

Hathaway, J., and Harvey, C., 'Framing refugee protection in the new world order’, Cornell International Law Journal 34 (2001) 257-318.

Human Rights Watch, In the Name of Counter-Terrorism: Human Rights Abuses Worldwide A Human Rights Watch Briefing Paper for the 59th Session of the United Nations Commission on Human Rights March 25, 2003.

Kapferer, S., 'Exclusion Clause in Europe: A Comparative Overview of State Practice in France, Belgium, and the United Kingdom', International Journal of Refugee Law, Vol. 12, Special Supplementary Issue (2000), 195221.

Van Krieken, P., 'Germany and Article 1F: "the Urgent Need to Implement a Basic Principle”', AWR-Bullentin: Vierteljahresschrift für Flüchtlingsfragen, 3-4 (2000) p. 189.

Van Krieken, P. (ed.), Refugee law in context. The exclusion clause, (The Hague: T.M.C. Asser Press, 1999).

Kälin, W. \& Künzli, J., 'Article 1F(b): Freedom Fighters, Terrorists and the Notion of Serious Non-Political Crimes', International Journal of Refugee Law, Vol. 12, Special Supplementary Issue (2000), 46-78.

Lauterpacht, E. and Bethlehem, D., 'The scope and content of the principle of non-refoulement', Opinion delivered in the framework of the global consultation, organized by UNHCR, 20 June 2001.

Lawyers committee for Human Rights 'Safeguarding the Rights of Refugees under the Exclusion Clauses: Summary Findings of the Project and a Lawyers Committee for Human Rights Perspective'.

Linderfalk, U., Om tolkning av traktater, (Studentlitteratur: Lund, 2001). 
Malanczuk, P,. Akehurst's Modern Introduction to International Law. 7th ed. (London/ New York: Routlegde, 1997).

Marx, R., 'Zu den Ausländer- und Asylrechtlichen Bestimmungen des Terrorismusbekämpfungsgestzes’, Zeitschrift für Ausländerrecht, 4 (2002), 127-136.

Pro Asyl, 'Rat Justiz und Inneres in Brüssel. Gemeinsames EU-Asylrecht droht an Deutschland zu scheitern’, Presseerklärung, 8. April 2003.

Renner, G., 'Aufenthaltsrechtliche Grundlagen für Arbeitserlaubnis und Sozialleistungen’, Zeitschrift für Ausländerrecht , 1 (1995) 14-22.

Renner, G., 'Terrorismusbekämpfung und Schutzsuchende', Zeitschrift für Ausländerrecht , 2 (2003), 52-59.

Restatement (Third) of the Foreign Relations Law of the United States.

Rikhof, J., 'Access, Asylum and Atrocities: An Unholy Alliance?', Refuge, 19/4 (2001), 100-115.

Sadat, L. N., 'Redefining universal jurisdiction', New England Law Review, 35/2 (2001), 241-263.

Storey, H., More Questions than Answers: The Exclusion Clauses in the Light of September 11, Paper for joint IARLJ/ILPA Seminar 4 March 2002.

Tampere European Council - Presidency Conclusions 16/10/1999 - Press: 0 Nr: 200/1/99.

Tomuschat, C., 'The Duty to Prosecute Crimes Committed by Individuals', in H.-J. Cremer et al (eds.), Tradition und Weltoffenheit des Rechts. Festschrift für Helmut Stenberger (Berlin: Springer, 2002).

UNCHR, Guidelines on the Application of the Exclusion Clauses, December 1996.

UNHCR, Handbook on Procedures and Criteria for Determining Refugee Status under the 1951 Convention and the 1967 Protocol relating to the Status of Refugees,

UNHCR, UNHCR and the Establishment of an International Criminal Court: Some Comments on the Draft Statute, available at $<$ http://www.un.org/icc/unhcr.htm>.

UNHCR, Observations on the European Commission's proposal for a Council Directive on minimum standards for the qualification and status of third country nationals and stateless persons as refugees or as persons who otherwise need international protection. P 10. 
UNHCR, UNHCR-Stellungnahme: Innere Sicherheit und Flüchtingschutz, 23. October 2001.

UNHCR, Stellungnahme zur Anhörung "Zuwanderungsgesetz" des Innenausschusses des Deutschen Bundestages am 16. Januar 2002, of 14 January 2002.

Weis, P., (ed.) The Refugee Convention, 1951: the Travaux Préparatoires Analysed with a Commentary, (Cambridge: Grotius Publications, 1995).

Werle, G., Implementation of the Rome Statute in Germany - The Future International Crimes Code, Paper presented at the EAPC/PfP Workshop on Prosecuting War Crimes, Interlaken, Switzerland, 17-19 October 2001.

Wirth, S., International Criminal Law in Germany, Presentation to the Conference Combating International Crimes Domestically, Hosted by the Canadian Department of Justice, Ottawa 22-23 April 2002.

Zink, K. F., Das Asylrecht in der Bundesrepublik Deutschland nach dem Abkommen vom 28. Juli 1951 über die Rechtsstellung der Flüchtlinge unter besonderer Berücksichtigung der Rechtsprechung der Verwaltungsgerichte, (Nürnberg: Staudacher. 1962)

Zimmermann, A., 'Bestrafung völkerrechtlicher Verbrechen duch deutsche Gerichte nach Inkrafttreten des Völkerstrafgesetzbuchs', Neue Juristische Wochenschrift 42 (2002), 3068-3070.

Zimmermann, A., Das neue Grundrecht auf Asyl. Verfassungs- und völkerrechtliche Grenzen und Voraussetzungen, (Berlin: Springer, 1994). 


\section{International instruments and documents}

Charter of the International Military Tribunal, 82 UNTS 280.

Commission Working Document The relationship between safeguarding internal security and complying with international protection obligations and instruments $\operatorname{COM(2001)~} 743$ final.

Convention (I) for the Amelioration of the Condition of the Wounded and Sick in Armed Forces in the Field. Geneva, 12 August 1949.

Convention (II) for the Amelioration of the Condition of Wounded, Sick and Shipwrecked Members of Armed Forces at Sea. Geneva, 12 August 1949.

Convention (III) relative to the Treatment of Prisoners of War. Geneva, 12 August 1949.

Convention (IV) relative to the Protection of Civilian Persons in Time of War. Geneva, 12 August 1949.

Convention Against Torture and Other Cruel, Inhuman and Degrading Treatment or Punishment, 10 December 1984, 1465 UNTS 85.

Convention relating to the Status of Refugees, 28 July 1951, 189 UNTS 137.

COUNCIL COMMON POSITION of 27 December 2001 on combating terrorism (2001/930/CFSP).

Council Directive 2001/55/EC of 20 July 2001 on minimum standards for giving temporary protection in the event of a mass influx of displaced persons and on measures promoting a balance of efforts between Member States in receiving such persons and bearing the consequences thereof. Official Journal L 212 , 07/08/2001 P. 0012 - 0023.

Declaration on the Human Rights of Individuals Who are not Nationals of the Country in which They Live, G.A. res. 40/144, annex, 40 U.N. GAOR Supp. (No. 53) at 252, U.N. Doc. A/40/53 (1985).

Draft Code of Crimes against the Peace and Security of Mankind, 8 ILC, $48^{\text {th }}$ Session, 6 May -26 July 1996, UN-Doc. A/CN.4/L.532.

European Convention on the Suppression of Terrorism, 27 January 1977, ETS. No. 90. 
ExCom, Standing Committee, Note on the Exclusion Clauses, 30 May 1997, EC/47/SC/CRP.29.

Hague Convention for the Suppression of Unlawful Seizure of Aircraft, 16 December 1970, 860 U.N.T.S. 105.

International Convention on the Suppression and Punishment of the Crime of Apartheid, adopted by U.N. G.A. Res. 3068 (XXVIII) of 30 November 1973.

JOINT POSITION of 4 March 1996 defined by the Council an the Basis of Article K.3 of the Treaty an European Union on the harmonized application of the definition of the term 'refugee' in Article 1 of the Geneva Convention of 28 July 1951 relating to the Status of refugees, O.J. 1996, L 63/2.

Proposal for a Council Directive on minimum standards for the qualification and status of third country nationals and stateless persons as refugees or as persons who otherwise need international protection, Brussels, 12.9.2001, $\operatorname{COM}(2001) 510$ final.

Protocol Additional to the Geneva Conventions of 12 August 1949, and relating to the Protection of Victims of International Armed Conflicts (Protocol I), 8 June 1977

Protocol Additional to the Geneva Conventions of 12 August 1949, and relating to the Protection of Victims of Non-International Armed Conflicts (Protocol II), 8 June 1977.

Statute of the international Court of Justice, 26 June 1945, UNTS XVI. Treaty establishing the European Community (TEC), Official Journal C 325 of 24 December 2002.

UN General Assembly Resolution on Measures to Eliminate International Terrorism (A/RES/49/60).

UN Security Council Resolution, S/RES/1373 (2001).

UN Security Council Resolution, S/RES/1269 (1999).

Vienna Convention on the Law of Treaties, May 23, 1969, UN Doc.

A/Conf. 39/27 


\section{Table of Cases}

Chahal v. the United Kingdom, European Court of Human Rights, 15 November 1996, Reports of Judgments and Decisions 1996-V.

Ramirez v Canada (Minister of Employment and Immigration) [1992] 2 FC 306 (CA).

Sivakumar v Canada (Minister of Employment and Immigration) [1994] 1 FC 433 (CA).

Soering v. the United Kingdom, European Court of Human Rights, 7 July 1989, Series A no. 161

T v Secretary of State for the Home Department HOUSE OF LORDS [1996] 2 All ER 865, [1996] 2 WLR 766.

BverfGE 68, 171= EZAR 200 Nr. 9.

BverfGE 80, 315 = EZAR 201 Nr. 20. 